

UNIVERSIDADE DE BRASÍLIA

INSTITUTO DE CIÊNCIAS HUMANAS - IH

DEPARTAMENTO DE GEOGRAFIA - GEA

\title{
PLANEJAMENTO E VULNERABILIDADE NA NOVA QNR, CEILÂNDIA
}

Bruno da Costa Monteiro

Prof $^{a}$. Dr ${ }^{a}$. Lúcia Cony Faria Cidade

Brasília

Junho de 2009 


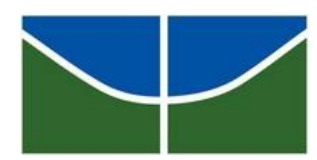

UNIVERSIDADE DE BRASÍLIA

INSTITUTO DE CIÊNCIAS HUMANAS - IH

DEPARTAMENTO DE GEOGRAFIA - GEA

\title{
PLANEJAMENTO E VULNERABILIDADE NA \\ NOVA QNR, CEILÂNDIA
}

\author{
Bruno da Costa Monteiro \\ Prof $^{\mathrm{a}}$. Dra ${ }^{\mathrm{a}}$. Lúcia Cony Faria Cidade \\ Monografia apresentada ao Departamento de Geografia, \\ da Universidade de Brasília - UnB, como requisito \\ parcial à obtenção do grau de Bacharel em geografia.
}

Brasília

Junho de 2009 


\title{
UNIVERSIDADE DE BRASÍLIA \\ INSTITUTO DE CIÊNCIAS HUMANAS - IH \\ DEPARTAMENTO DE GEOGRAFIA - GEA
}

Monografia apresentada ao Departamento de Geografia, da Universidade de Brasília UnB, como requisito parcial à obtenção do grau de Bacharel em Geografia.

\section{PLANEJAMENTO E VULNERABILIDADE NA NOVA QNR, CEILÂNDIA}

\author{
Bruno da Costa Monteiro
}

Aprovado por:

Professora orientadora: Lúcia Cony Faria Cidade

Professor: Dante Flávio da Costa Júnior

Professor: Gilberto Alves de Oliveira Junior

Brasília, 30 Junho de 2009. 


\section{DEDICATÓRIA}

À minha mãe, Lucia Sampaio da Costa Monteiro. Ao meu pai, José de Queiroz Monteiro.

À minha noiva Tatiana Moura Batista por ser sempre companheira. 


\section{AGRADECIMENTOS}

A professora e orientadora Lúcia Cony Faria Cidade, por me incentivar na melhora do trabalho, pelas recomendações de leitura e pelas contribuições para o trabalho no decorrer da elaboração desta monografia. 


\section{LISTA DE FIGURAS}

FIGURA 1 - Projeto original de Ceilândia. 1970 ........................................................... 16

FIGURA 2 - Malha urbana da Ceilândia: caracterização por regiões............................ 19

FIGURA 3 - Projeto da Área Perimetral Norte .............................................................. 24

FIGURA 4 - Nova QNR, início da construção das residências. 2003............................ 26

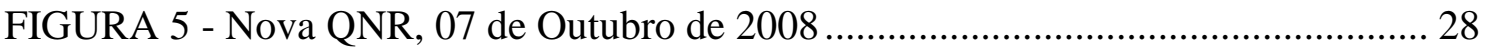




\section{LISTA DE MAPAS}

MAPA 1 - Nova QNR delimitada de acordo com os limites atuais 


\section{LISTA DE FOTOGRAFIAS}

FOTOGRAFIA 1 - Águas servidas jogadas no meio da rua, QNR 02 .......................... 32

FOTOGRAFIA 2 - Saída de águas servidas direto para rua, QNR 05 .......................... 33

FOTOGRAFIA 3 - Exemplo de fossa transbordando, QNR 04 ................................... 34

FOTOGRAFIA 4 - Galpão Comunitário, QNR 04, nas proximidades de uma fossa .... 35

FOTOGRAFIA 5 - Via entre a as residências da QNR 02 e as áreas especiais............. 36

FOTOGRAFIA 6 - Lixos acumulados na Área Especial da QNR 02 ........................... 37

FOTOGRAFIA 7 - Única via da Nova QNR ainda não asfaltada................................ 38

FOTOGRAFIA 8 - Residência da QNR 05 de frente com a BR 070............................. 39 


\section{LISTA DE TABELAS}

TABELA 1 - Distribuição da área urbana da Ceilândia, 1997.

TABELA 2 - Previsão de equipamentos públicos comunitários e urbanos 30 


\author{
APN - Área Perimetral Norte \\ CEI - Campanha de Erradicação de Invasores \\ DF - Distrito Federal \\ EPC - Equipamento Público Comunitário \\ EPU - Equipamento Público Urbano \\ GDF - Governo do Distrito Federal \\ JK - Juscelino Kubitschek \\ MDE - Memorial Descritivo \\ NOVACAP - Nova Capital do Brasil \\ PAC - Programa de Aceleração do Crescimento \\ PDL - Plano Diretor Local \\ PDOT - Plano Diretor de Ordenamento Territorial \\ PEOT - Plano Estrutural de Ordenamento Territorial \\ PUB - Parâmetro Urbanístico Básico \\ RA - Região Administrativa
}




\section{SUMÁRIO}

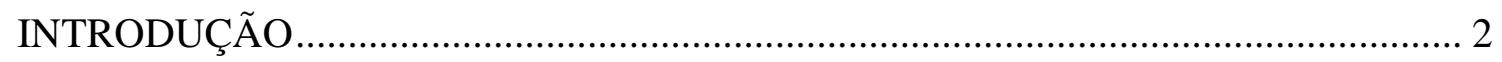

CAPÍTULO 1: FUNDAMENTAÇÃO TEÓRICA …..................................................... 6





CAPÍTULO 2: GESTÃO TERRITORIAL NO DISTRITO FEDERAL ........................ 10

2.1. Antecedentes: História da criação do Distrito Federal ....................................... 10

2.2. Expansão urbana de Brasília: das origens à atualidade ..................................... 11

CAPÍTULO 3: GESTÃO TERRITORIAL NA CEILÂNDIA ....................................... 14

3.1. Antecedentes: História da criação da Ceilândia.................................................. 14

3.2. Expansão urbana de Ceilândia: das origens à atualidade.................................... 15



3.3. Distribuição populacional da Ceilândia ............................................................ 21

CAPÍTULO 4: GESTÃO TERRITORIAL E VULNERABILIDADE NA NOVA QNR

4.1. Expansão urbana da Nova QNR: das origens à atualidade................................ 23

4.2. Planejamento Urbano nas quadras da Nova QNR …......................................... 29

4.3. Vulnerabilidade socioambiental na Nova QNR.............................................. 31

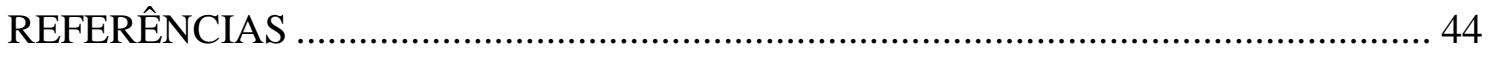




\section{INTRODUÇÃO}

Aspectos gerais

O Distrito Federal (DF) foi, desde o seu processo de criação, uma área de intensos fluxos migratórios causando uma rápida e desorganizada expansão territorial. Dentro deste contexto podemos citar a cidade satélite da Ceilândia que foi uma forma de resolver os problemas de invasões, construção em locais não permitidos pela administração da região, ocorridos ao longo da década de 60 .

A Ceilândia, em seu projeto inicial, foi planejada e dividida em dois lados: QNM e QNN e sua criação foi necessária para evitar as constantes invasões que estavam aparecendo ao redor do Plano Piloto. Porém, esses novos lotes, do projeto inicial da Ceilândia, não foram suficientes para suportar o enorme fluxo de migrações que ocorreram no Distrito Federal e foram, então, surgindo novas áreas de expansão como é o caso do Setor "P" Sul, Setor "P" Norte e o Setor "O”. Estas quadras não foram as últimas a aparecem na Ceilândia, depois que elas se consolidaram, começaram a surgir outras que neste trabalho chamaremos de áreas periféricas e extensões periféricas (OLIVEIRA, 2006).

Um exemplo da extensão periférica é a Nova QNR, que é o conjunto de quadras da QNR de número 2, 3, 4 e 5. Estas novas quadras situam-se na região norte da Ceilândia, afastada de outras quadras. Embora exista um planejamento inicial, pouco realmente foi feito deste planejamento o que gerou um aumentando da vulnerabilidade da população residente. Este trabalho analisa as relações entre planejamento, gestão do território e vulnerabilidade em Ceilândia, com foco na Nova QNR.

A principal característica de Brasília é de ser uma cidade planejada, antes e depois de sua construção, porém, apesar de ser uma característica de Brasília, nem sempre é possível executar com eficiência os planos propostos pelo planejamento, o que acaba por gerar problemas como formação de invasões ao redor de Brasília.

As invasões que ocorreram principalmente próximas a Brasília foram sendo erradicas e levadas para pontos distantes da mesma, o que configura o cenário atual do Distrito Federal. O problema maior encontra-se devido à falta de ajuda do governo na consolidação dos erradicados em um novo espaço. 
Ceilândia é uma parte da história que surgiu por causa de invasões, foi modificada por um projeto e sofreu com a falta de infra-estrutura. Ceilândia conta com mais de 343.694 habitantes, tomando como base o último censo (IBGE, 2000). Hoje estes problemas estão voltando com as novas ocupações; a Nova QNR é um exemplo. A Nova QNR é parte de um planejamento, previsto no Plano Diretor de Ordenamento Territorial (PDOT 2007) e também no Plano Diretor Local de Ceilândia (PDL 2000), porém, apenas algumas das políticas pretendidas foram consolidadas. Apesar do planejamento prévio, as casas que ali surgiram não receberam o devido apoio do governo.

A discussão leva às seguintes questões de pesquisa:

1 - Como se relaciona a forma de ocupação que veio ocorrendo no território de Ceilândia com a ocupação das quadras periféricas?

2 - Qual o papel das ações governamentais diante de áreas de risco e vulnerabilidade socioambiental na Nova QNR?

Objetivos

O objetivo geral é analisar as relações entre planejamento e vulnerabilidade na Ceilândia.

Objetivos específicos são:

1. Analisar a forma de ocupação que veio ocorrendo no território de Ceilândia, para que seja possível fazer uma comparação com as últimas quadras que surgiram.

2. Analisar as propostas do planejamento e as diferenças nas ações governamentais na Nova QNR, buscando identificar áreas de risco e vulnerabilidade socioambiental.

Como ainda não existem estudos sobre esta região e bem como existe uma carência de informação sobre as expansões ocorridas depois da Expansão do Setor “O”, este trabalho poderá servir de base para posteriores projetos. 
Procedimentos Metodológicos

Para responder à primeira questão de pesquisa que, no pano de fundo de Brasília, trata da ocupação territorial de Ceilândia, este trabalho utiliza como base livros, dissertações de mestrado e publicações em geral.

Para responder à segunda questão de pesquisa, que trata da ocupação territorial da Nova QNR, este trabalho utiliza como fontes de estudos: livros, dissertações e publicações em geral, além de levantamentos obtidos através observação direta e entrevistas informais com a líder comunitária das QNR, e também com a representante da Escola Classe 65. As informações obtidas pela líder comunitária foram sobre a questão de infra-estrutura na área da Nova QNR e história das construções na região. Pela representante da Escola Classe 65 foram obtidas informações a respeito dos problemas enfrentados pelos moradores da Nova QNR e também pelos estudantes.

Os dados utilizados foram de fontes oficiais, para que haja maior confiabilidade, com informações relativas à infra-estrutura, bem estar e lazer, além de registros fotográficos realizados pelo autor

Para uma avaliação mais geral foram utilizado mapas de diferentes datas para que possa haver uma comparação da evolução das casas e dos equipamentos comunitários.

Para uma avaliação melhor detalhada foram realizadas duas saídas de campo, com aproximadamente 1 ano de diferença entre cada visita, para avaliar e entender as políticas territoriais da região em estudo. A primeira saída de campo foi no dia 05 de junho de 2008 e a segunda foi realizado no dia 04 de junho de 2009.

Para o desenvolvimento desta monografia, serão apresentados 4 capítulos. O Capítulo 1, Fundamentação Teórica mostra alguns conceitos importantes para o entendimento do trabalho como um todo. Este capítulo está dividido da seguinte forma: Planejamento e Vulnerabilidade.

O Capítulo 2 tem como principal função fazer um histórico de Brasília, desde a sua criação até o ano de 2009. Além disso, compromete-se a fazer uma breve reflexão sobre a expansão urbana no território do DF, buscando suas origens e tentando relacionar com a Ceilândia. O mesmo foi organizado da seguinte forma: Antecedentes: 
História da criação do Distrito Federal; Expansão urbana de Brasília: das origens à atualidade.

No Capítulo 3 será abordado uma pequena parte da gestão territorial da Ceilândia no contexto histórico, este capítulo servirá de base para que seja possível entender como foi o surgimento desta cidade e bem como as expansões territoriais até o ano de 2009. Este capítulo está organizado da seguinte forma: Antecedentes: História da criação da Ceilândia; Expansão urbana de Ceilândia; Distribuição populacional da Ceilândia.

O Capítulo 4 mostra a região estudada com foco no planejamento e na vulnerabilidade socioambiental. Este capítulo está dividido em: Expansão urbana da Nova QNR: das origens à atualidade; Planejamento urbano nas quadras da Nova QNR: das origens a atualidade; Planejamento Urbano nas quadras da Nova QNR; Vulnerabilidade socioambiental na Nova QNR. 


\section{CAPÍTULO 1: FUNDAMENTAÇÃO TEÓRICA}

O objetivo deste capítulo é servir de base para os principais conceitos que serão abordados, iniciando com o conceito de planejamento para que depois seja possível falar de vulnerabilidade.

\subsection{Planejamento}

Antes de falar sobre os diversos planejamentos que ocorreram no território brasileiro, se faz necessária a sua conceituação. O planejamento em si pode ser entendido como um ato de se preparar seguindo um roteiro pré-estabelecido e utilizando métodos determinados. Visa estabelecer objetivos que são metas, diretrizes que são as estratégias e procedimentos que são as metodologias para a obtenção dos fins determinados (FONSECA, 2007. p 38). Neste trabalho será utilizado apenas três das diversas finalidades de planejamento que são elas: planejamento do desenvolvimento, planejamento urbano e planejamento estratégico.

No processo de gestão de um território, o planejamento deve ser analisado como sendo a etapa mais importante, tendo em vista que nesta etapa as ações preventivas para o uso dos recursos naturais devem ser avaliados cuidadosamente para evitar eventuais impactos (FONSECA, 2007. p 51).

\subsubsection{Planejamento do desenvolvimento}

A idéia de planejamento do desenvolvimento é para estimular principalmente o desenvolvimento econômico e geralmente é utilizada em grandes escalas sendo ela mais aconselhada para cidades grandes, estados ou para o país como um todo.

A visão estratégica no planejamento do desenvolvimento serve para organizar as ações de forma a ligar um processo de transformações na direção do novo estilo de desenvolvimento, preparando a médio e a longo prazo. Assim, as estratégias prioritárias devem ser concentradas nos problemas de maior importância. Esta não é uma forma de ignorar os problemas locais, porém é fundamental atuar seletivamente sobre problemas de grande importância, para evitar o contínuo problema de urgências e necessidades (BUARQUE, 1999, p. 40). 


\subsubsection{Planejamento Urbano}

O planejamento em si surge como resposta a diversos problemas enfrentados nas diversas cidades, tanto aqueles ainda não resolvidos pela urbanização moderna, quanto aos causados por ela. A expressão planejamento urbano vem da Inglaterra e dos Estados Unidos, e é um marco na mudança da forma de encarar as cidades e seus problemas (SABOYA, 2008).

Algumas mudanças foram importantes para que o conceito de planejamento urbano fosse formado, dentre estas mudanças as mais importantes foram: o reconhecimento do fenômeno urbano como algo dinâmico, levando a encarar a cidade como resultado de sua própria história; a mudança introduzida no planejamento, com ênfase na busca pelo modelo de cidade real ao invés de ideal (SABOYA, 2008).

\subsubsection{Planejamento Estratégico}

O planejamento estratégico surge no panorama dos estudos de planejamento urbano da década de 1980 e o seu conceito pode ser definido como sendo uma transposição dos conceitos do planejamento de empresas para o planejamento urbano como afirma Kaufman (Apud SABOYA, 2008). Esta forma de planejamento vem sendo utilizado em várias cidades e recentemente no Brasil. O planejamento estratégico de cidades segundo Güell pode definir-se como:

... uma forma sistemática de conduzir as mudanças e criar o melhor futuro possível para uma cidade. Mais especificamente, o planejamento estratégico é um processo criativo que define às bases de uma atuação integrada a longo prazo, estabelece um sistema contínuo de tomada de decisões que comporta riscos, identifica a direção de ações específicas, formula indicadores sobre os resultados e envolve os agentes sociais e econômicos locais ao longo de todo o processo (GÜELL, 1997, apud ARGILES, 2003, p. 39).

Tal expressão tem relação também com a palavra estratégia, que deve ser entendida como sendo uma ação que visa dominar determinado território.

Em todas as correntes, a definição de estratégias implica na análise das potencialidades (forças) e fraquezas internas e de ameaças e oportunidades externas que contribuem para a obtenção dos objetivos. Assim, identificamse os fatores sobre os quais a organização tem meios e condições de agir, 
exercendo alguma influência, no sentido de se mudar o futuro a partir das condições do presente. (GDF, 2004).

Existem críticas a este modelo de estratégia, ressaltam que o mesmo é essencialmente voltado a desenvolver o potencial econômico local, na teoria este modelo deveria dedicar-se às questões sociais e à qualidade de vida no meio urbano. Uma característica deste modelo é o fato dele ser aberto a adequações ou desvios de tendências, permitindo uma evolução na forma de planejamento (ARGILES, 2003, p. 36-37).

A utilização do termo "planejamento estratégico" nas cidades, esta unida ao idéia de gerenciar o desenvolvimento da cidade, de diagnosticar suas potencialidades e problemas e buscar direcionar esforços no sentido de abranger uma ampla gama de fatores que possam motivar o desenvolvimento (ARGILES, 2003, p. 37).

A maior diferença entre o planejamento estratégico e os outros tipos de planejamento é que o primeiro visa metas de curto prazo, enquanto os outros visam metas de médio e longo prazo. O planejamento estratégico focaliza em alternativas e caminhos para aproveitar novas oportunidades.

\subsection{Vulnerabilidade}

A palavra vulnerabilidade é ampla e pode ter significados diferentes se focados em campos diferentes. Esta palavra está, em muitos casos, associado a um indicador de algo com efeito negativo. Segundo Moser, citada por Alves (2006, p. 45) a noção de vulnerabilidade geralmente é definida como uma situação que estão presentes três elementos (ou componentes): exposição ao risco; incapacidade de reação; e dificuldade de adaptação diante da materialização do risco.

No campo social, a vulnerabilidade é uma predisposição individual para apresentar resultados negativos no desenvolvimento (MASTES M; GARMEZY, 1985). Pode ser também um ou vários indicadores sociais, como por exemplo: distâncias sociais existentes entre diferentes grupos demográficos, grau de riqueza entre diversos grupos, condições de habitação numa determinada região.

Existem outros fatores que vulnerabilizam as pessoas e estes não são determinados apenas por aspectos econômicos, como é o caso da fragilização dos 
vínculos afetivo-relacionais e de pertencimento social (discriminações etárias, étnicas, de gêneros, por deficiência). Existem também os fatores vinculados à violência, ao território, à representação política dentre outros (ALMEIDA, 2005, p. 2).

\begin{abstract}
“(...) Os eventos que vulnerabilizam as pessoas não são apenas determinados por aspectos de natureza econômica. Fatores como a fragilização dos vínculos afetivo-relacionais e de pertencimento social (discriminações etárias, étnicas, de gênero ou por deficiência...), ou vinculados à violência, ao território, à representação política dentre outros, também afetam as pessoas. Segundo Francisco de Oliveira, as situações de vulnerabilidade podem ser geradas pela sociedade e podem ser originárias das formas como as pessoas (as subjetividades) lidam com as perdas, os conflitos, a morte, a separação, as rupturas.” (ALMEIDA, 2005, p. 2)
\end{abstract}

No campo físico, sobre o ambiente onde encontram-se os moradores, podemos relacionar com a vulnerabilidade ambiental.

(...) Vulnerabilidade ambiental pode ser compreendida como o risco de degradação do ambiente natural, relacionada à erosão do solo, perda de biodiversidade, assoreamento, contaminação do recurso solo - água, etc. (Anais XIII, 2007. p. 2493)

Unindo o campo social e o campo ambiental, surge a vulnerabilidade socioambiental, que é a coexistência ou sobreposição espacial dos grupos de baixa renda e áreas de risco (ALVES, 2006).

Neste trabalho será abordado o conceito de vulnerabilidade socioambiental e como indicadores serão utilizados os relacionados à pobreza e à degradação ambiental. Como indicadores sociais serão abordados problemas relacionados à renda e à condições de habitação. Como indicadores ambientais, serão utilizados problemas relacionados ao saneamento, no caso a coleta e tratamento de lixo e esgoto e abastecimento de água potável. 


\section{CAPÍTULO 2: GESTÃO TERRITORIAL NO DISTRITO FEDERAL}

Este capítulo visa avaliar as principais mudanças que ocorreram no território do Distrito Federal, desde a sua primeira idéia até o ano de 2009.

\subsection{Antecedentes: História da criação do Distrito Federal}

A idéia de construir uma nova capital no centro geográfico do país estava prevista na primeira constituição republicana de 1891. Porém somente no ano de 1956, quando Juscelino Kubitschek (JK) assumiu a presidência do Brasil este plano seria concretizado, pois ele tinha como um dos principais objetivos a construção de Brasília. Em 19 de setembro de 1956 o então presidente sanciona a Lei n. ${ }^{\circ}$ 2.874, que delimitava o território do Distrito Federal e definia a mudança da capital do Brasil, antigo Rio de Janeiro, para Brasília (GDF, 2009).

O primeiro planejamento que gerou experiência para o Brasil foi o "Plano de Metas”, elaborado no mandato de JK, no período que foi de 1956 até 1960. Este pode ser considerado como o primeiro plano nacional de sentido estratégico onde foram estabelecidos metas a serem atingidas e é considerado um exemplo de planejamento estratégico. A construção de Brasília caracterizava-se como sendo a meta-síntese do Plano. Em 21 de Abril de 1960, de acordo com o Plano de Metas, surge Brasília, situada no território do Distrito Federal e foi idealizada próxima as margens do Lago Paranoá.

Este local foi projetado para suportar até 700 mil habitantes, com previsão de que aconteceria no ano de 2000 (PELUSO; OLIVEIRA, 2006, p. 11). Logo após a inauguração de Brasília, começou a existir uma grande migração de habitantes de outros estados devido ao desenvolvimento industrial brasileiro. Brasília acabou se tornando um centro urbano e encontrava-se num ponto estratégico, no centro do país, visando beneficiar toda extensão nacional. (SILVA, 1983).

A urbanização brasileira se intensifica em paralelo com o surgimento de pequenos e médios centros urbanos que articulavam-se próximos ao centro do país. A localização de Brasília é estratégica, pois visa atender a necessidade de articular as diferentes regiões do país, com a circulação de produtos industriais. 
Neste sentido, a localização territorial de Brasília é estratégica ao buscar responder à necessidade de articulação do sudeste com o Centro-Oeste e Norte, para permitir o escoamento da produção da região, a penetração dos produtos industriais e dar infra-estrutura para a penetração do capital (FERREIRA, 1985).

A cidade necessitava ser uma centralidade e também precisava de um rápido desenvolvimento na sua infra-estrutura devido ao enorme contingente populacional, que viriam diretamente para Brasília. Grande uma parte desse contingente não conseguiu fixar-se na capital, onde havia as melhores condições de vida, e tiverem que se fixar em áreas próximas. Devido a este fato os moradores foram se aglomerando em favelas.

2.2. Expansão urbana de Brasília: das origens à atualidade

Cidades costumam surgir de forma planejada, Brasília é um exemplo, como mostra no subitem anterior. O seu crescimento deveria ser feita de forma controlada e com infra-estrutura, mas devido ao grande fluxo migratório, não foi possível oferecer esta mesma infra-estrutura para as demais cidades que foram surgindo.

Brasília entre os anos de 1956 a 1969, ainda encontrava-se em fase de Construção, comportando-se como cidade pioneira. Ela surgiu para ser uma cidade de pequenas proporções, porém, o fluxo migratório foi maior do que se esperava, trazendo um rápido contingente para o mercado de trabalho que, em grande maioria, era caracterizado pela construção de obras de grande porte. Nesta mesma época, surgiram as primeiras cidades-satélites, como por exemplo, Taguatinga, Gama e parte do Paranoá. Cidades como Brazlândia e Planaltina tiveram um rápido crescimento e o Plano Piloto foi estabilizado. A população do Distrito Federal que era de quase 140,1 mil passou para 537,5 com apenas nove anos de sua fundação (CODEPLAN-GDF, 1997). Brasília em 1969 chegou a ter 70.128 favelados como afirma Furtado:

Em 1969, com apenas nove anos de fundação, Brasília já tinha 70.128 favelados, que moravam em 14.607 barracos, em condições subumanas, para uma população prevista de 500 mil habitantes em todo o Distrito Federal. Naquele ano, foi realizado em Brasília um seminário sobre problemas sociais no Distrito Federal. (FURTADO, 2003, p. 5) 
Já na fase de Consolidação, entre os anos de 1970 até 1985 há um esgotamento da capacidade de criação de novos postos de trabalho e nesta época Brasília começa a ter uma expansão em seu território, grande parte surge nas proximidades da capital, formando pequenas favelas. Em 1971, o governo tomou algumas medidas para minimizar as invasões, dentre as medidas, foram feitas algumas retiradas de favelas para locais distantes de Brasília, como é o caso de Ceilândia. Neste mesmo contexto, para que haja um planejamento prévio, com base no crescimento anual, o Governo do Distrito Federal consolida a construção de represas como a de Santa Maria e de Santo Antônio Descoberto, visando garantir o abastecimento do contingente cada vez maior. Em 1977, com o objetivo de definir diretrizes para a alocação de novos assentamentos foi elaborado o Plano Estrutural de Organização Territorial do Distrito Federal (PEOT). No período de 1970 até 1985, houve um rápido crescimento populacional, porém menor do que o período anterior, sendo de aproximadamente 537,5 mil para 1,176,9 mil habitantes.

Na fase de Expansão, a partir de 1986, houve algumas mudanças que tornaram a capital do Brasil uma região menos propícia à migração, dentre elas estão o esgotamento dos espaços do Planto Piloto e a falta de emprego. Para evitar um grande número de moradores concentrados próximos ao Plano Piloto, o Governo foi distribuindo terras em outros locais, distantes da capital, como é o caso de Samambaia, Sobradinho II, Varjão e a ampliação do Paranoá que se localizavam próximas as áreas de risco.

Em meados de 90, surge mais uma mancha urbana no DF, a cidade de Águas Claras, que se encontra em uma ótima localização, próxima ao Plano Piloto e próximo às cidades satélites. É ainda nesta década conseguimos encontrar um crescimento rápido horizontal e vertical no DF. Apesar do nível de crescimento populacional não se manter no mesmo nível de outras décadas, as cidades continuaram a crescer, o que gerou um adensamento da área urbanizada. Na tentativa de enfrentar os inúmeros problemas que se apresentavam e de estabelecer uma organização territorial planejada, o governo agenciou diversos planos e estudos: O Plano de Ordenamento Territorial (POT 1985); Brasília revisada 85-87; o Plano de Ocupação e uso do Solo do Distrito Federal (POUSO 1986-1990); o Plano Diretor de Ordenamento Territorial (PDOT 1992); e o 
Plano Diretor de Ordenamento Territorial e Urbano do Distrito Federal (PDOT 1997) (DIAS DA SILVA, 2003, p. 54). ${ }^{1}$

Ao longo do capítulo foi possível perceber que Brasília não estava bem preparada para suportar o crescente número de pessoas e apesar de haver diversos planejamentos as ações efetivas não foram suficientes para oferecer uma qualidade de vida adequada aos moradores, particularmente nas cidades satélites como Ceilândia.

\footnotetext{
${ }^{1}$ Até o ano de 2009, esta em uso o PDOT revisado
} 


\title{
CAPÍTULO 3: GESTÃO TERRITORIAL NA CEILÂNDIA
}

Este capítulo pretende servir de base para a exploração da primeira questão de pesquisa, que investiga como se relaciona a forma de ocupação que veio ocorrendo no território de Ceilândia com a ocupação das quadras periféricas. Para entender um pouco mais sobre as invasões é necessário que haja uma perspectiva histórica sobre a Ceilândia e suas novas quadras.

\subsection{Antecedentes: História da criação da Ceilândia}

Como foi mostrado no capítulo anterior o DF contava com muitos favelados em 1969 e nesta época já estava em seu auge de consolidação, todas as suas Regiões Administrativas (RA) eram independentes entre si. No referido ano, houve um seminário para decidir o que seria feito com os moradores irregulares que estava construindo barracos próximos ao Plano Piloto e a decisão tomada pelo governo foi erradicar as favelas. A este plano de erradicação chamou-se de Campanha de Erradicação de Invasores (CEI).

\begin{abstract}
Em 27 de março de 1971, Vera Prates da Silveira, mulher do então governador do Distrito Federal, Hélio Prates da Silveira, lançou a campanha de Erradicação de Invasões - CEI, conseguindo transferir os moradores das Vilas do IAPI, Tenório, Esperança, Bernado Sayão e Colombo, além dos Morros do Querosene, Urubu, Placa da Mercedes e do Curral das Éguas. (Arquivo, 2001, p. 14, Apud Ceilândia: Resgate Histórico, 2005, p. 13).
\end{abstract}

O Nome "Ceilândia" surgiu da idéia do então Secretário Otomar Lopes Cardoso, que resolveu unir as siglas "CEI" com uma palavra de origem inglesa "lândia" que significa cidade. O sufixo somente veio ser adotado porque sufixos em inglês estavam na moda (FURTADO, 2003, p. 5). Ceilândia, após a CEI representava $30 \%$ da população de Brasília, foram demolidos cerca de 15.000 barracos e levou aproximadamente nove meses para que a remoção dos moradores, para a nova área, fosse concretizada (Arquivo, 2001, p. 14, Apud Ceilândia: Resgate Histórico, 2005, p. $13)$. 
3.2. Expansão urbana de Ceilândia: das origens à atualidade

No final da década de 70 a Ceilândia estava se tornando mais complexa, do que a RA de Taguatinga, tornando-se inviável administrá-la com apenas uma administração, porém, foi na década de 80 que começaram a surgir a preocupação em dividi-la. Somente pelo Decreto $\mathrm{n}^{\mathrm{o}} 11.921$ de 25 de outubro de 89 , que fixa os novos limites das Regiões Administrativos do Distrito Federal, Ceilândia deixa de ser parte de Taguatinga e passa a tornar-se uma Região Administrativa.

\begin{abstract}
Com o crescimento da população, e a imensa gama de problemas que surgem naturalmente quando da criação de uma cidade, tornou-se necessária a criação de uma administração própria. Na década de 80, aconteceram os primeiros movimentos pela emancipação administrativa, intensificados a partir de 1985. No dia 03 de junho de 1986, o então Governador José Aparecido de Oliveira, assinava a mensagem n ${ }^{\circ}$ 10/86, submetendo ao Exmo. Sr. Presidente da República, o anteprojeto de Lei, propondo a criação de novas regiões administrativas, entre elas a de Ceilândia-RA IX, o que só iria acontecer em 25 de outubro de 1989, com a assinatura do Decreto no 11.921/89, pelo Exmo. Sr. Governador do Distrito Federal (FURTADO, 2003, p. 7)
\end{abstract}

Como uma Região Administrativa, foram consolidadas novas quadras, como é o caso do Setor "O", construída em 1976 pela antiga SHIS ${ }^{2}$. Setor "P" Sul e o Setor "P" Norte, foram uma das últimas quadras a serem implantadas no território da Ceilândia, ano de 1979, e foi organizado de forma a seguir o padrão original, da Ceilândia, lembrando que estas novas casas também foram construídas no padrão da SHIS.

Houve todo um planejamento para o remanejamento dos habitantes e em 1971 já havia a demarcação de 17.619 lotes, de 10x25 metros, numa área de aproximadamente $20 \mathrm{~km}^{2}$. Esta área foi demarcada pela Nova Capital do Brasil (NOVACAP) em 97 dias (FURTADO, 2003, p. 6). Reunindo estes lotes eles formariam o formato de um barril como mostra na Figura 1, projeto proposto pelo arquiteto urbanístico Ney Gabriel de Souza. Em 27 de março de 1971 foi colocada a pedra fundamental no local onde se encontra a caixa d'água, ao lado da feira do centro de Ceilândia. $O$ formato original da Ceilândia estava dividido em dois grandes Setores o "M" e o "N" e pode ser mais bem definido, geograficamente, como: Ceilândia Sul que engloba as quadras da QNM 01 até

\footnotetext{
${ }^{2}$ SHIS é uma antigas construtora e foi responsável pela construção das casas da Ceilândia, em seu planejamento inicial, ela concentrava a produção das unidades habitacionais dos assentamentos urbanos promovidos pelo poder Público
} 
09 e da 17 até a 25; Ceilândia Norte que vai das quadras QNM 02 até a 10 e da QNN 18 até a 26; Ceilândia Oeste indo das quadras QNN 01 até a 09 e da 17 até a 25; Por fim a Ceilândia Centro que enquadra a CNM 01 e 02 e também a CNN 01 e 02.

FIGURA 1 - Projeto original de Ceilândia. 1970
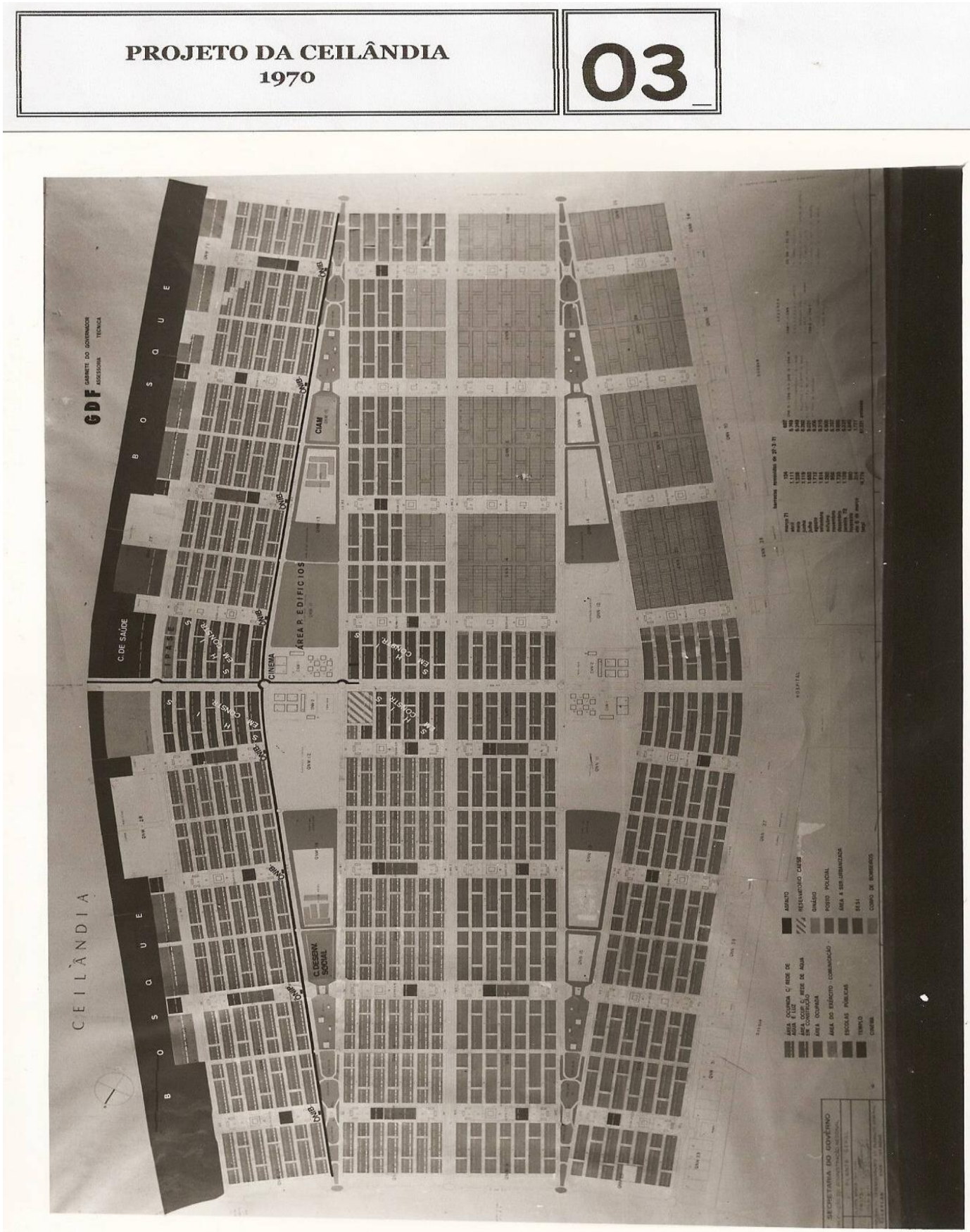

Fonte: Acervo histórico da Ceilândia, 1970. 
Apesar de sua inauguração ter sido na década de 70 e várias outras quadras surgirem nesta época, Ceilândia somente pode ser considerada adequada, em termos de instrumento comunitário, no início da década de 80 onde foram construídos os primeiros postos médicos, implementado asfalto nas ruas e houve a criação de mais escolas públicas.

Na década de 80, pode ser verificada uma falta de habitação próxima a Brasília, o que fez com que houvesse um inchaço populacional nas cidades-satélites que já estavam consolidadas. Para suprir as necessidades habitacionais que estavam ocorrendo no território do DF, foram criadas algumas áreas para abrigar novos habitantes e em 1985 foi inaugurada a quadra de expansão da Ceilândia chamada de Expansão do Setor "O". Com a sua criação, pôde notar-se que a qualidade de vida destes novos moradores era inferior aos moradores já consolidados anteriormente, como os do Setor "O". Ainda na década de 80 , as quadras do Setor "P" Sul e do Setor "N" receberam novas quadras onde a primeira recebeu as quadras 22, 24 e também o Setor "Q" e o Setor "N" recebeu as quadras de QNN 35 a 40.

Na década de 90, foram concretizadas algumas áreas de expansão horizontal, como é o caso do Setor "R", consolidada em 1992 e é também considerado um assentamento, onde o seu processo de implantação de assentamento foi realizado de forma gradual, de acordo com a ocupação da região.

A auto-construção é a forma dominante de produção da moradia e a implantação da infra-estrutura básica ocorre posteriormente à ocupação da área, a qual ocorre a partir do parcelamento do solo, da delimitação dos lotes e da instalação de pontos provisórios de infra-estrutura básica para atendimento da comunidade" (FURTADO, 2003, p. 8).

O Setor "R" é um exemplo de autoconstrução, e seu assentamento ocorreu no de 1992. Este foi sendo concretizado juntamente com o processo de ocupação da área.

\subsection{Organização espacial de Ceilândia}

A classificação de períodos estabelecidos nos subtítulos subseqüentes, não é determinada de forma exata, tendo em vista que algumas áreas dentro destas classificações ainda hoje sofrem modificações e/ou sofreram em outras épocas. 


\subsection{1. Áreas urbanas consolidadas, período de 1971 até 1976}

As áreas consolidadas da Ceilândia foram as que estavam programadas na CEI, servindo para evitar os barracos que situavam-se ao redor do Plano Piloto. Esta área, como pode ser vista na Figura 2, é bem organizada e juntas fazem o formato de barril. Os lotes seguiram um padrão de tamanho de aproximadamente $250 \mathrm{~m}^{2}$ e foram construídos nos moldes da construtora SHIS. Nesta região existe uma boa infraestrutura e os moradores contam com melhores benefícios do que os moradores de outras regiões da Ceilândia, pois podem contar com o metrô que segue acima da pista N2, as residências são próximas as escolas, comércios, áreas de lazer e postos de saúde. As ruas são todas asfaltadas e as pistas são largas. 
FIGURA 2 - Malha urbana da Ceilândia: caracterização por regiões.



Fonte: Google Earth. Data da imagem: 07 de Outubro de 2008. Adaptação feita pelo autor.

\subsection{2. Áreas planejadas, período 1976 até 1985}

As áreas planejadas diferenciam-se das Consolidadas pelo fato de não serem projetadas dentro da Campanha de Erradicação de Invasões, porém, estas foram construídas seguindo o projeto de expansão territorial e populacional que serviria de moradia para novos invasores. Nesta região encontramos o Setor "O", consolidado em 1976 e o Setor "P" Sul e "P" Norte, consolidados em 1989.

O Setor “O”, que engloba as quadras da QNO, segue os mesmos padrões que as áreas consolidadas, já á região do "P" Sul e do "P" Norte seguiram outro tipo de padrão, onde, no centro de cada quadra, encontra-se uma área de lazer e/ou uma escola. 
Inicialmente, as quadras da QNO, Setor “O”, pertenciam a Taguatinga (RA III), porém, devido à semelhança que esta quadra apresenta com relação à Ceilândia, bem como com os aspectos político-administrativos, elas foram inseridas como parte da Região Administrativa da Ceilândia. Estas novas áreas, assim como as áreas consolidadas, possuem residências com tamanhos regulares e uma boa infra-estrutura.

\subsection{3. Áreas periféricas, período de 1985 até 1992}

Neste período surgiram as novas expansões da Ceilândia, dentre elas a Expansão do Setor "O", expansão das quadras na região do Setor "N", do Setor "P" Sul e do Setor “Q”. Nesta área podemos notar, até mesmo pela Figura 2, que os lotes não seguem padrão algum e as ruas são tortas. Esta região tem pouca infra-estrutura. As áreas de equipamentos coletivos como campos de futebol e quadras de esporte são depredados e abandonados, as ruas são geralmente sujas e os bueiros, que servem para escoar a água, costumam estar entupidos com lixo, geralmente jogado pelos próprios moradores. As entrequadras têm uma péssima iluminação pela parte da noite, o que as tornam perigosas.

A parte residencial é diferente das outras duas citadas acima, pois os lotes e as calçadas são pequenos. Os lotes são geralmente menores do que $130 \mathrm{~m}^{2}$ e quanto maior a distância entre estas novas cidades e as áreas consolidadas, menor são as ruas e as calçadas.

Com freqüência encontram-se entulhos nas entrequadras, o que acaba gerando problemas no solo e também traz problemas para os moradores, principalmente para as crianças que costumam brincar próximas aos entulhos.

\subsection{4. Áreas de extensão periférica período de 1992 até 2009}

Neste período surgiram as novas regiões, dentre elas o Setor "R", em 1992, a Área de Desenvolvimento Econômico Centro-Norte, em 1999 e Área Perimetral Norte, 
em 2002. Esta é uma das últimas áreas a ser consolidada e como foi mostrado nos subitens anteriores, as novas áreas foram surgindo com menos apoio do governo. Em sua grande parte, há ausência de saneamento básico, principalmente na Nova QNR, onde em suas casas não é encontrado o sistema de esgoto e coleta de lixo. Esta área é desvalorizada devido à falta de ações governamentais e também devido à distância que existe até os grandes centros.

Esta região é caracterizada pelas suas residências que apresentam lotes pequenos, num padrão próximo aos padrões da Expansão do Setor “O”, porém, com um estreitamento no tamanho dos lotes residenciais. As casas em grande parte são construídas com tijolo e o portão, em algumas casas, é feito de arame farpado. É comum também encontrar casas feitas de madeirite.

Esta é uma área que apresenta vulnerabilidade no âmbito sócio-ambiental, constituindo-se como o ponto que se encontra mais afastado do centro, o que gera condições adversas, já que apesar dos problemas citados acima, ela não teve investimentos públicos na sua infra-estrutura. A Nova QNR é onde podemos encontrar os maiores problemas dentro de Ceilândia.

\subsection{Distribuição populacional da Ceilândia}

Pelos dados da CODEPLAN, a população da Ceilândia era de 330.899 habitantes em 1997, representando $18,87 \%$ da população do DF e sua taxa de crescimento anual e de $-0,59 \%$. Em 2000 o IBGE realizou outro senso e segundo este a população era de 343.694 habitantes

Com base na Tabela 1, dos 330.899 habitantes que existem na Ceilândia, 117.570 moram na parte Consolidada (Centro, Ceilândia Sul, Ceilândia Norte e Guariroba) que como já foi mencionado tem os melhores equipamentos urbanos e 213.329 moram na área Planejada, Periférica e Extensão Periférica, ou seja, a maior parte dos moradores da Ceilândia encontram-se nas áreas em que não são beneficiados com ótimos equipamentos, enquanto uma minoria vive com melhor infra-estrutura e por conseqüência têm melhores qualidades de vida. 
TABELA 1 - Distribuição da área urbana da Ceilândia, 1997

\begin{tabular}{|c|c|c|c|c|c|c|}
\hline SETOR & $\begin{array}{c}\text { TOTAL } \\
\text { DE } \\
\text { LOTES }\end{array}$ & $\begin{array}{l}\text { ÁREA DA } \\
\text { QUADRA* }\end{array}$ & $\begin{array}{c}\text { ÁREA DA } \\
\text { QUADRA } \\
* *\end{array}$ & $\begin{array}{l}\text { POPULA- } \\
\text { ÇÃO } \\
\text { (IBGE- } \\
\text { 1996) }\end{array}$ & $\begin{array}{c}\text { DENSI- } \\
\text { DADE } \\
\text { LÍQUIDA } \\
\text { (Hab./Ha) }\end{array}$ & $\begin{array}{c}\text { DENSIDADE } \\
\text { BRUTA } \\
\text { (Hab./Ha) }\end{array}$ \\
\hline Centro & 3.595 & $1.491 .032,147$ & $2.627 .600,00$ & 17.940 & 120,32 & 68,27 \\
\hline $\begin{array}{c}\text { Ceilândia } \\
\text { Sul }\end{array}$ & 4.945 & $1.575 .441,171$ & $2.698 .000,00$ & 31.541 & 200,20 & 116,90 \\
\hline $\begin{array}{l}\text { Ceilândia } \\
\text { Norte }\end{array}$ & 4.937 & $1.517 .570,171$ & $2.607 .000,00$ & 32.657 & 215,19 & 125,26 \\
\hline Guariroba & 6.483 & $1.066 .285,171$ & $2.335 .800,00$ & 35.432 & 332,29 & 151,69 \\
\hline $\begin{array}{l}\text { Ceilândia } \\
\text { Oeste }\end{array}$ & 4.916 & $1.347 .370,171$ & $2.335 .800,00$ & 35.304 & 262,02 & 151,14 \\
\hline $\begin{array}{c}\text { Nova } \\
\text { Guariroba }\end{array}$ & 653 & $306.052,660$ & $472.200,00$ & 2.741 & 89,56 & 58,05 \\
\hline $\begin{array}{c}\text { Nova } \\
\text { Ceilândia }\end{array}$ & 632 & $353.338,584$ & $565.100,00$ & 2.860 & 80,94 & 50,61 \\
\hline Setor "O" & 7.603 & $1.447 .578,910$ & $3.175 .300,00$ & 35.423 & 244,70 & 111,58 \\
\hline Expansão & 5.611 & $1.114 .307,465$ & $1.947 .050,00$ & 32.650 & 293,01 & 167,69 \\
\hline "P" Sul & 12.017 & $1.694 .376,000$ & $3.315 .200,00$ & 61.612 & 363,63 & 185,85 \\
\hline "P" Norte & 6.140 & $1.059 .062,156$ & $1.828 .100,00$ & 28.690 & 270,90 & 156,94 \\
\hline QNQ & 2.381 & $363.011,985$ & $638.000,00$ & 11.427 & 314,78 & 179,11 \\
\hline QNR & 659 & $125.944,000$ & $364.500,00$ & 2.054 & 163,09 & 56,35 \\
\hline Industrial & 1.890 & $993.000,000$ & $1.713 .900,00$ & 568 & 5,72 & 3,31 \\
\hline Mat. Const. & 413 & $413.291,400$ & $680.400,00$ & 0 & 0,00 & 0,00 \\
\hline ADE & 625 & $210.089,94$ & $593.932,12$ & 0 & 0,00 & 0,00 \\
\hline $\begin{array}{l}\text { Perimetral } \\
\text { Norte }\end{array}$ & 2.522 & & $2.404 .421,66$ & $* * *$ & 0,00 & 0,00 \\
\hline TOTAL & 63.500 & 15.077.751,93 & 30.302.303,7 & 330.899 & 219,46 & 118,61 \\
\hline
\end{tabular}

Fonte: NOT-RA IX, 1997

* Área Liquida em Metros Quadrados

** Área Bruta em Metros Quadrados

*** A população de projeto prevista para a Área Perimetral Norte é de 11.500 habitantes.

Ainda com base na Tabela 1, as regiões da Ceilândia têm uma enorme disparidade residencial, onde dos 63.500 lotes existentes, apenas 13.000 são das Áreas Consolidadas os outros lotes estão distribuídos nas outras regiões existentes da Ceilândia. Isso mostra que nas outras áreas da Ceilândia existe uma enorme rede populacional e que moram em pequenas casas.

Como foi visto neste capítulo sobre Ceilândia, podemos notar que as novas áreas que estão surgindo estão sendo cada vez mais precárias, com péssima infra estrutura e piores condições de vida. Em muitos casos existe um estreitamento dos lotes e uma maior densidade populacional. A Nova QNR, que será foco do próximo capítulo é um exemplo claro dessa precarização onde nas suas quadras as casas são menores e existe um maior número de moradores por metro quadrado. 


\section{CAPÍTULO 4: GESTÃO TERRITORIAL E VULNERABILIDADE NA NOVA QNR}

Este capítulo pretende servir de base para a exploração da segunda questão de pesquisa, que investiga qual o papel da gestão do território na constituição de áreas de risco e vulnerabilidade socioambiental na Nova QNR.

4.1. Expansão urbana da Nova QNR: das origens à atualidade

\subsubsection{Antecedentes}

A região onde hoje se encontra a Nova QNR é uma área que constantemente era alvo de invasões residenciais e de chácaras e que gradativamente veio sendo ocupadas através de licenças concedidas pelo GDF.

Com a aprovação do PDOT, em 28 de janeiro de 1997, ficou estabelecido que Ceilândia teria uma nova área para servir de expansão urbana e ficou caracterizada como zona urbana de dinamização. Porém, somente no dia $1^{\circ}$ de Setembro de $2000 \mathrm{com}$ a lei complementar de no 314 surge o Plano Diretor Local da Ceilândia (PDL), onde foi delimitada esta nova região e chamada por ele de Área Perimetral Norte (APN).

No PDL 2000 da Ceilândia fica estabelecido no Art. 12, Inciso I que a APN será para uso urbano e deverá ser objeto de projetos urbanísticos especiais. A delimitação da APN encontra-se a oeste do Setor "P" Norte e da QNR 01 e tem aproximadamente e 2.607.412,819 m². A Figura 2 mostra com detalhes a delimitação desta área. 
FIGURA 3 - Projeto da Área Perimetral Norte

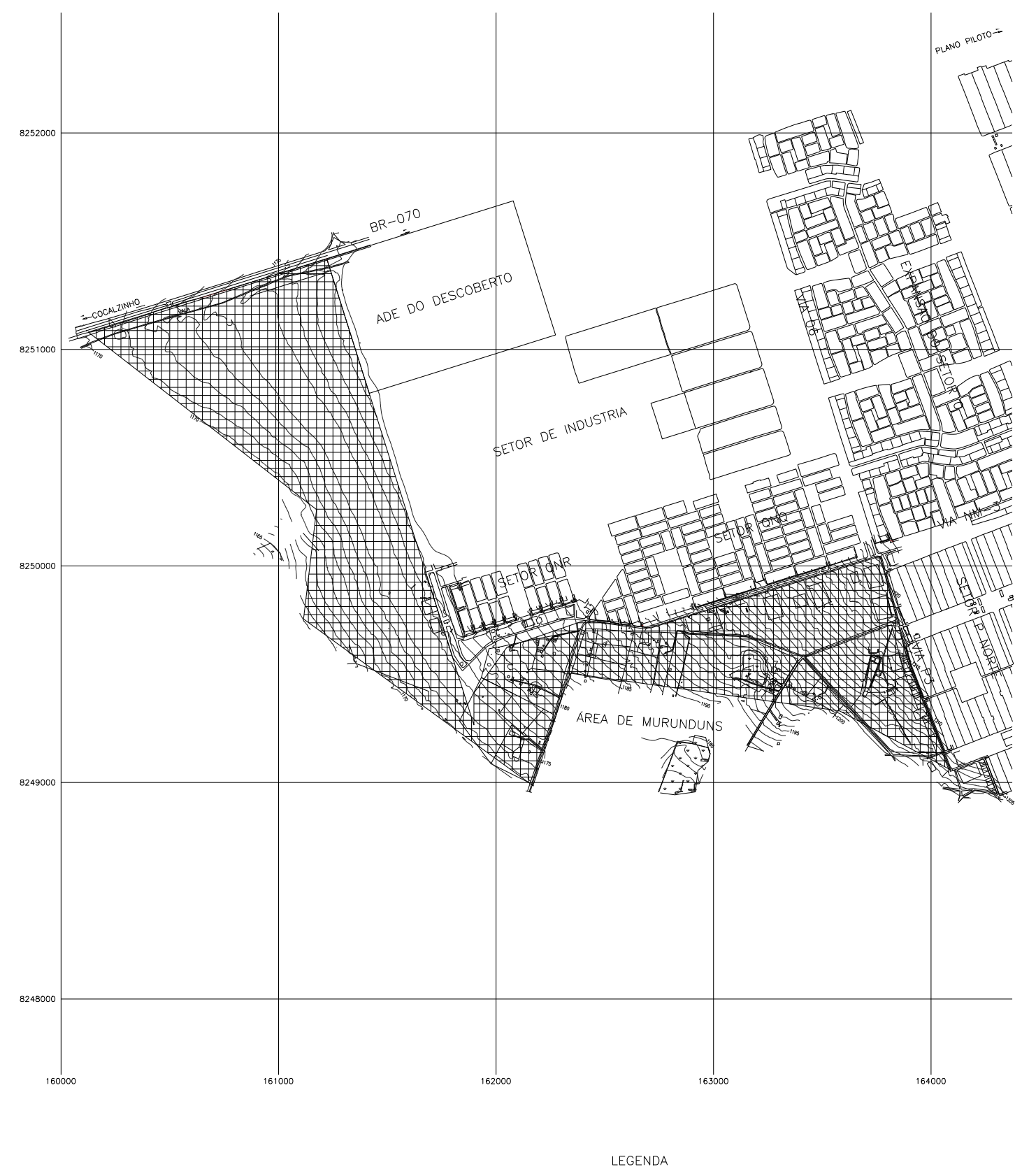

$\# \#$ ÁREA PERIMETRAL NORTE

Fonte: Memorial Descritivo 016, 2002.

Esta área não foi escolhida por acaso, houve todo um estudo para que a mesma fosse proposta ao GDF. O projeto foi aprovado por estudos climáticos, geológicos, hidrológicos, bióticos e outros de locais de proteção. 
Do ponto de vista climático o resultado é que não existem restrições, porém, deixam-se algumas ressalvas, que poderiam ocorrer problemas por causa da erosão, devido a forte chuvas e também devido aos ventos. (MDE 016/02, p.10)

Com base em estudos geológico/geomorfológico a única ressalva que é feita diz respeito à predominância de solos argilosos, o que exige um maior cuidado com as fundações das edificações que irão ser implantadas. (MDE 016/02, p.10)

Sob o ponto de vista hidrológico o relatório deixa claro que deve haver um cuidado especial no que diz respeito a fossas, pois de acordo com o relatório técnico das sondagens realizadas na área o lençol freático encontra-se em níveis que variam entre 4,50m e 1,00m. (MDE 016/02, p.11)

Do ponto de vista biótico concluiu-se que não existe quase nada da vegetação nativa devido à intensa interferência humana tanto no desmatamento quando na ocupação desorganizada. (MDE 016/02, p.11)

Sobre os locais a proteger fica a ressalva de que locais que encontrarem-se nas proximidades de nascentes e áreas de murunduns. (MDE 016/02, p.12)

Note que em momento algum houve uma recusa da região como local para a ocupação territorial houveram apenas algumas ressalvas. Com a aprovação do projeto começaram-se as distribuições de casas e logo após a ocupação.

\subsubsection{Início da ocupação territorial na Nova QNR}

O processo de ocupação territorial na Nova QNR não ocorreu de forma rápida, foi ocorrendo gradativamente. O processo de implantação destes assentamentos foi realizado junto com o processo de ocupação da área, assim que os moradores recebiam os lotes do governo já começavam-se as obras.

A QNR 4 foi a primeira quadra a se consolidar como mostra a Figura 4. As casas desta quadra foram entregues pelo GDF em 2002 para alguns grupos de pessoas. O processo de ocupação foi lento, porque existiam regras para estes grupos, e grande parte deles não cumpriam os critérios estabelecidos pelo governo. A forma de ocupação da QNR 4 é diferente das outras que surgiram depois, pois elas seriam distribuídas de acordo com a remoção de invasões em diferentes locais do DF. 
FIGURA 4 - Nova QNR, início da construção das residências. 2003.

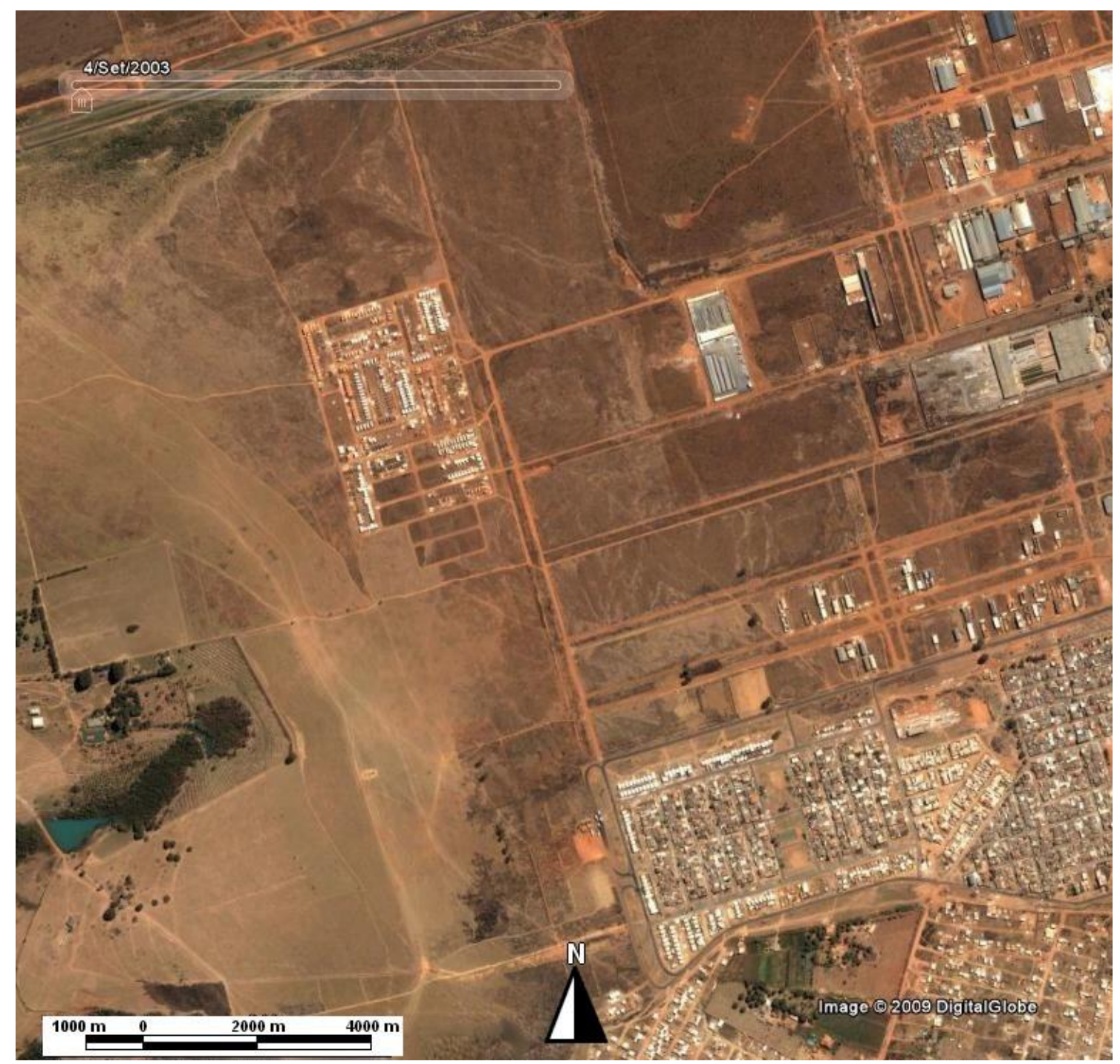

Fonte: Google Earth. Data da imagem: 04 de Setembro de 2003. Modificações feitas pelo autor.

Ainda com base na Figura 4, podemos verificar o início da construção das residências na Nova QNR, a parte já ocupada na figura é a QNR 4. Apesar das primeiras construções terem começado primeiramente por esta quadra as outras já estavam delimitadas tanto em áreas residenciais como em áreas especiais. As áreas especiais são áreas destinadas aos equipamentos públicos de uso urbano e comunitário.

As quadras 2 e 3 foram as penúltimas quadras a se consolidarem no território da Nova QNR, estas começaram a ser ocupadas a partir de 09 de Novembro de 2004, quando o GDF, resolveu retirar os moradores de uma invasão conhecida como Invasão do Estádio Pelezão, no Guará, próximo ao Parque Shopping. Na antiga invasão foram removidas 187 famílias (GDF, 2004). Outros lotes que foram surgindo vieram de uma invasão no Setor "P" Sul, Ceilândia, próxima da quadra 28. 
A QNR 5 foi a última quadra a se consolidar e surgiu devido ao apoio do governo em abrigar os moradores da antiga Vila Rafael, que situava-se no Setor "O". No dia 13 de Setembro de 2006, houve um incêndio nesta vila, que deixou cerca de 286 famílias sem moradia, o GDF como medida removeu estes moradores para esta nova região que hoje encontra-se próxima à rodovia BR-070 (Brasília-Corumbá).

Apesar de não ser possível fazer um estudo utilizando imagens de satélite para fazer uma comparação histórica desta região, sabe-se que a ocupação ocorreu em aproximadamente dois anos de diferença entre uma ocupação e outra. Até chegarmos à configuração atual.

Em 2008, todas as áreas residenciais da Nova QNR já estavam ocupadas como mostra a Figura 5. Estes área, porém, não seguiram completamente a organização proposta pela administração de Ceilândia, pois, onde encontra-se a QNR 05, no projeto original deveria ser as Áreas Especiais da QNR 04. Outra diferença da idéia inicial, esta no tamanho das residências da QNR 05, pois são menores do que as residências das quadras vizinhas, devido a quantidade de moradores vindos da Vila Rafael e do espaço disponível. 
FIGURA 5 - Nova QNR, 07 de Outubro de 2008

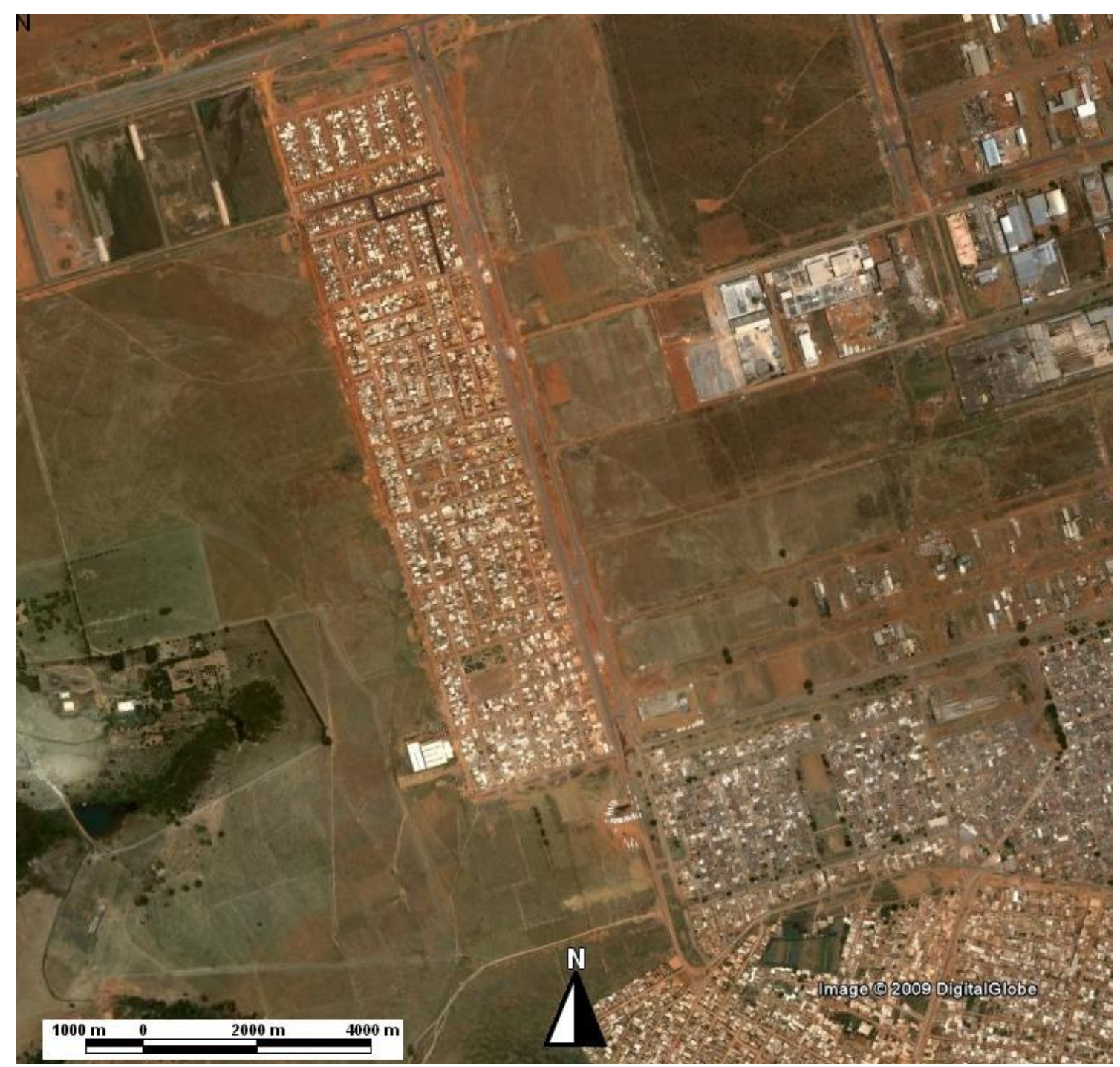

Fonte: Google Earth. Data da imagem: 07 de Outubro de 2008. Modificações feitas pelo autor.

O Mapa 1, da próxima página, mostra a Nova QNR, organizada e dividida de acordo com a configuração atual, com delimitação tanto para as quadras residenciais quanto para as áreas especiais. 
MAPA 1 - Nova QNR delimitada de acordo com os limites atuais

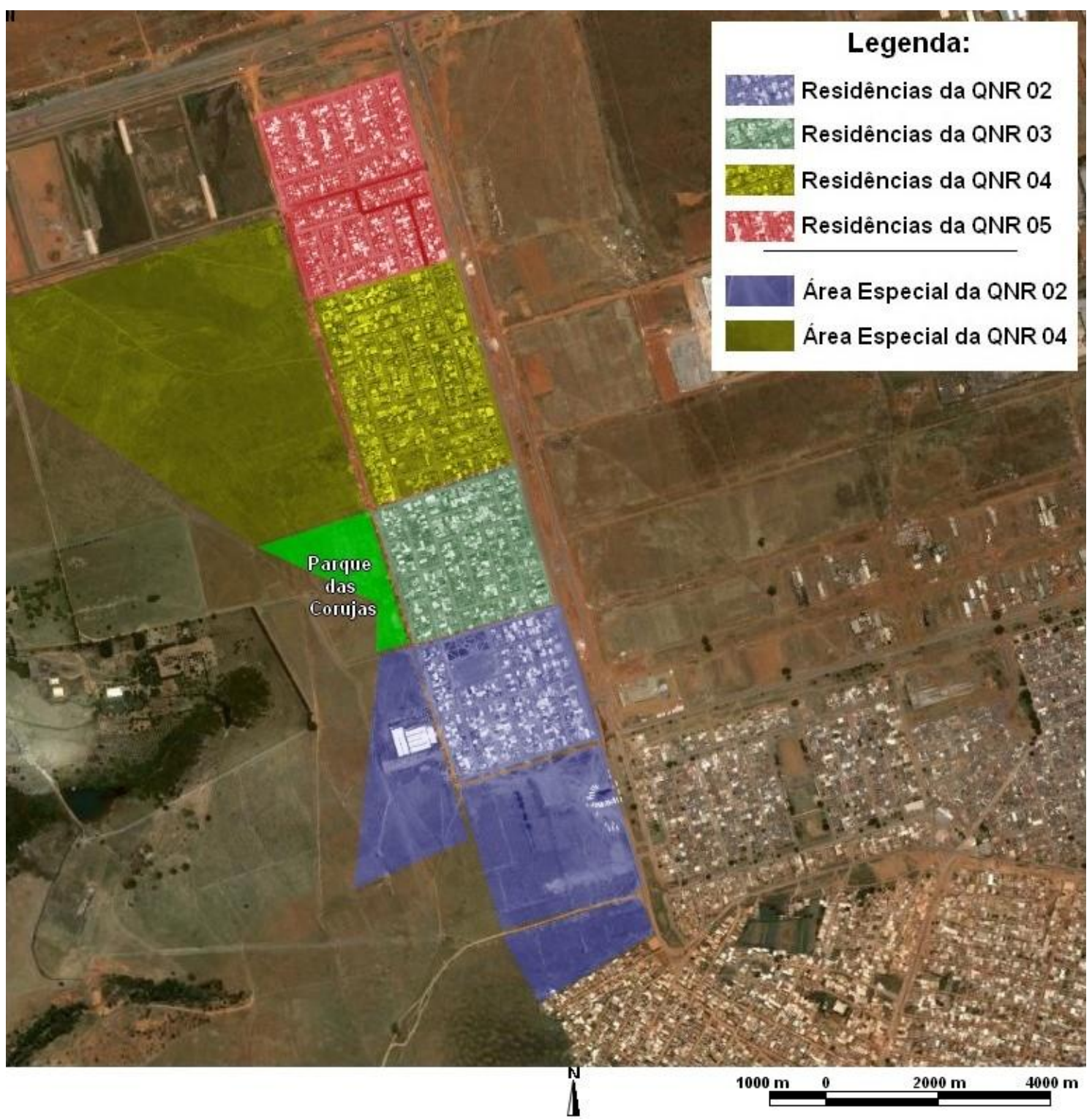

Fonte: Google Earth. Data da imagem: 07 de Outubro de 2008. Modificações feitas pelo autor.

4.2. Planejamento Urbano nas quadras da Nova QNR

\subsubsection{Ações Governamentais}

A Nova QNR começou a ser beneficiada com melhores condições de infraestrutura somente a partir do repasse do Programa de Aceleração do Crescimento (PAC). O PAC infra-estrutura, anunciado no dia 03 de Agosto de 2007 visa a construção de obras de urbanização, com a finalidade de transformar assentamentos precários em bairros com infra-estrutura, dentro deste projeto já previa o benefício para 
os moradores da Nova QNR. Este recurso foi passado para o GDF e com ele foi criado o Pró-Moradia.

O Pró-Moradia é um programa do GDF que visa atender as regiões mais necessitadas do DF e contam com um recurso de mais de 21 milhões de reais. (GDF, 2008). Dos 21 milhões, 13,2 milhões seriam destinados à construção de sistema de drenagem pluvial e pavimentação asfáltica nas quadras da Nova QNR, bem como uma quadra esportiva na QNR 03. Grande parte do dinheiro utilizado no Pró-Moradia veio do PAC infra-estrutura. Este programa serviu para concretizar os recursos fornecidos, em grande parte, pelo governo federal. Dos recursos utilizados no Pró-Moradia podemos verificar apenas os únicos benefícios que se concretizaram foi o asfaltamento da Nova QNR e também o sistema de drenagem pluvial aos moradores da QNR 02, 03 e 04, a quadra 05 ainda não conta com este benefício.

\subsubsection{Possíveis projetos para a Nova QNR}

Podemos encontrar o projeto do que deverá existir nas quadras da Nova QNR. Este projeto encontra-se na Tabela 2 onde cita quais serão os equipamentos comunitários para atender os moradores: delegacia de polícia, terminal de ônibus, corpo de bombeiro, secretaria de saúde, secretaria de educação entre outros. Estes equipamentos públicos podem ser melhor explicados com base na Tabela 2.

TABELA 2 - Previsão de equipamentos públicos comunitários e urbanos

\begin{tabular}{|c|c|c|c|}
\hline EQUIPAMENTO & ENDEREÇO & ÁREA m2 & USOS \\
\hline 1) Delegacia de Polícia & QNR 02 - Área Especial 11 & $10.600,00$ & EPC \\
\hline 2) Terminal de Ônibus DMTU & QNR 02 - Lote 01 & $32.670,00$ & EPU \\
\hline 3) Corpo de Bombeiros & QNR 04 - Área Especial 14 & $5.976,00$ & EPC \\
\hline 4) Secretaria de Saúde & QNR 02 - Área Especial 12 & $14.254,85$ & EPC \\
\hline 5) Regimento de Cavalaria & QNR 02 - Lote 02 & $34.881,65$ & EPC \\
\hline 6) Parque de Exposições & QNR 04 - Área Especial 22 & $222.300,03$ & $\mathrm{EPC}$ \\
\hline 9) Secretaria de Educação & $\begin{array}{l}\text { QNR } 02 \text { - Área Especial } 01 \\
\text { QNR } 04 \text { - Área Especial } 01\end{array}$ & $\begin{array}{l}3.058,50 \\
3.058,50\end{array}$ & EPC \\
\hline 10) CAESB & $\begin{array}{l}\text { QNR } 02 \text { - Área Especial } 10 \\
\text { QNR } 04 \text { - Área Especial } 23\end{array}$ & $\begin{array}{l}2.138,56 \\
1.562,19\end{array}$ & EPU \\
\hline
\end{tabular}

Fonte: Memorial Descritivo 016, 2002. 
A QNR 02 dentre as quadras da Nova QNR é a área que possuirá o maior número de equipamentos públicos tanto para uso comunitário quanto para uso urbano. Estes maior número de equipamentos na quadra 2 servirá para atender os moradores da QNR 01 e também os moradores do Condomínio Por do Sol, que não possuem nenhum destes equipamentos.

Das previsões de equipamentos público da Tabela 2 o único equipamento existente é o terminal de ônibus, que hoje conta com uma frota muito pequena de ônibus. Como equipamento urbano, não citado na Tabela 2, existe o Galpão comunitário, inaugurado dia 04 de abril e oferece comida as terças e quinta e também oferece serviços a comunidade, como alfabetização aos maiores de 40 anos, todos os beneficiados são moradores da Nova QNR.

É notável a carência de equipamentos públicos nas novas quadras e o que se pode verificar é que esta carência tende a afetar diretamente os moradores. Serviços básicos que deveriam existir, não existem nem em projeto, como é o caso do esgoto. Devido a esta carência encontramos moradores em regiões de risco como será mostrado na seção posterior.

\subsection{Vulnerabilidade socioambiental na Nova QNR}

A forma de produção de construção da Nova QNR foi a auto-construção, construir por contra própria sem esperar a implantação de infra-estrutura básica. Apesar de não terem outras opções, este foi um dos principais motivos dos problemas existentes nesta região, pois assim como a QNR I teve pouca ajuda do Governo para se consolidar, a Nova QNR está enfrentando este mesmo problema, devido a esta falta de infraestrutura. Os moradores da Nova QNR encontram-se em situações de vulnerabilidade socioambiental.

A contaminação do solo é um problema freqüente nestas quadras. Na primeira saída de campo, foi possível notar que quase todas as casas jogavam águas servidas nas ruas, como é mostrado na Fotografia 1. Águas servidas são aquelas utilizadas em lavagem de roupa, louça entre outros usos. O problema ocorre quando estas águas são 
jogadas em grande excesso e acumulam poças que se infiltram no solo, sujando os lençóis freáticos com sabão e outros produtos.

FOTOGRAFIA 1 - Águas servidas jogadas no meio da rua, QNR 02

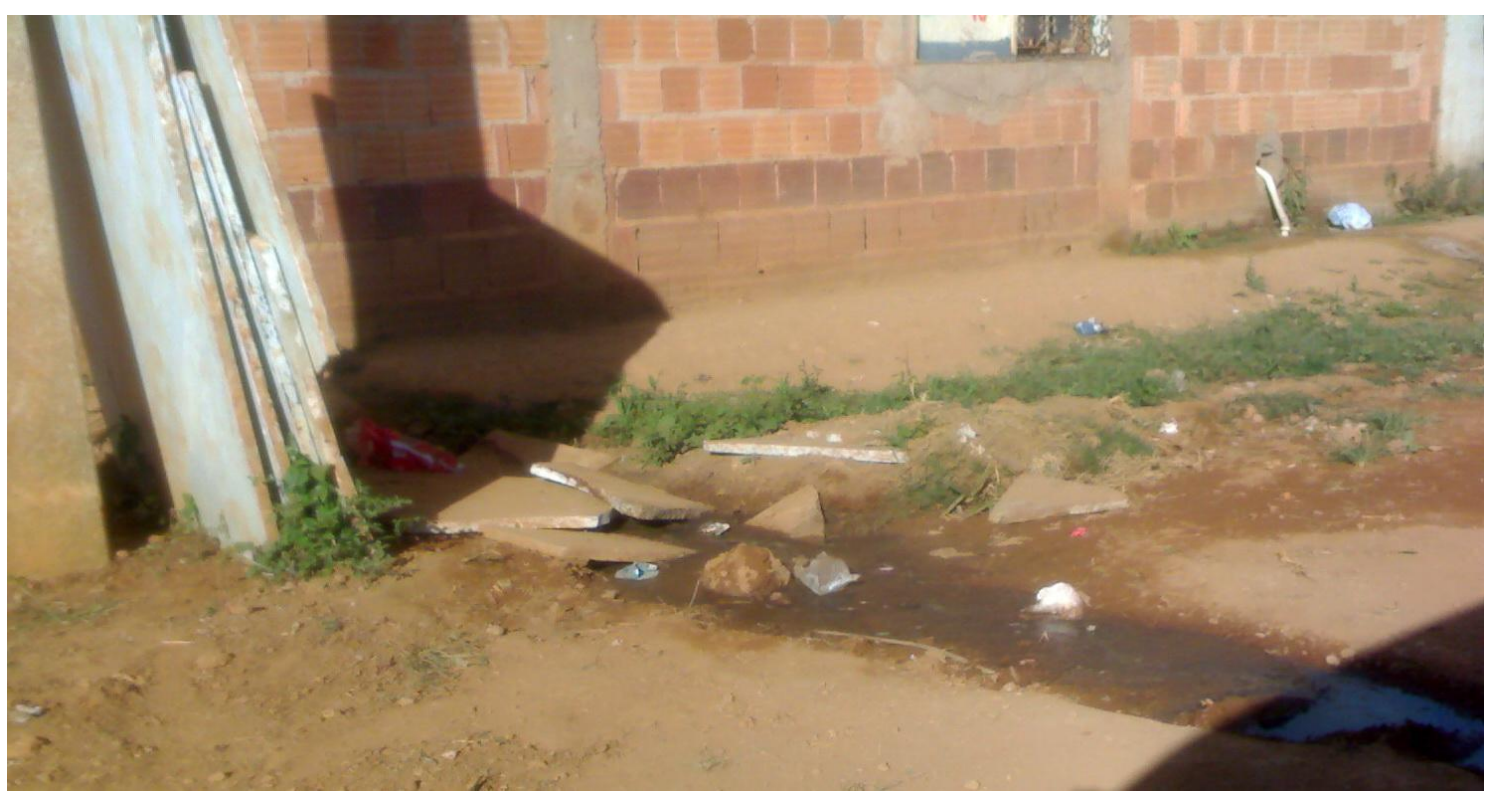

Foto: Bruno da Costa Monteiro, 05 de Junho de 2008.

Antes da construção do asfalto, o governo pediu para que os moradores jogassem as águas servidas em suas próprias fossas, porém, muitos dos moradores não fizeram as mudanças proposta pelo governo. A Fotografia 2 foi registrada na segunda saída de campo e mostra uma residência da QNR 05, na frente desta casa já esta asfaltada e ao lado encontra-se a única parte da Nova QNR que ainda não foi asfaltada. 
FOTOGRAFIA 2 - Saída de águas servidas direto para rua, QNR 05

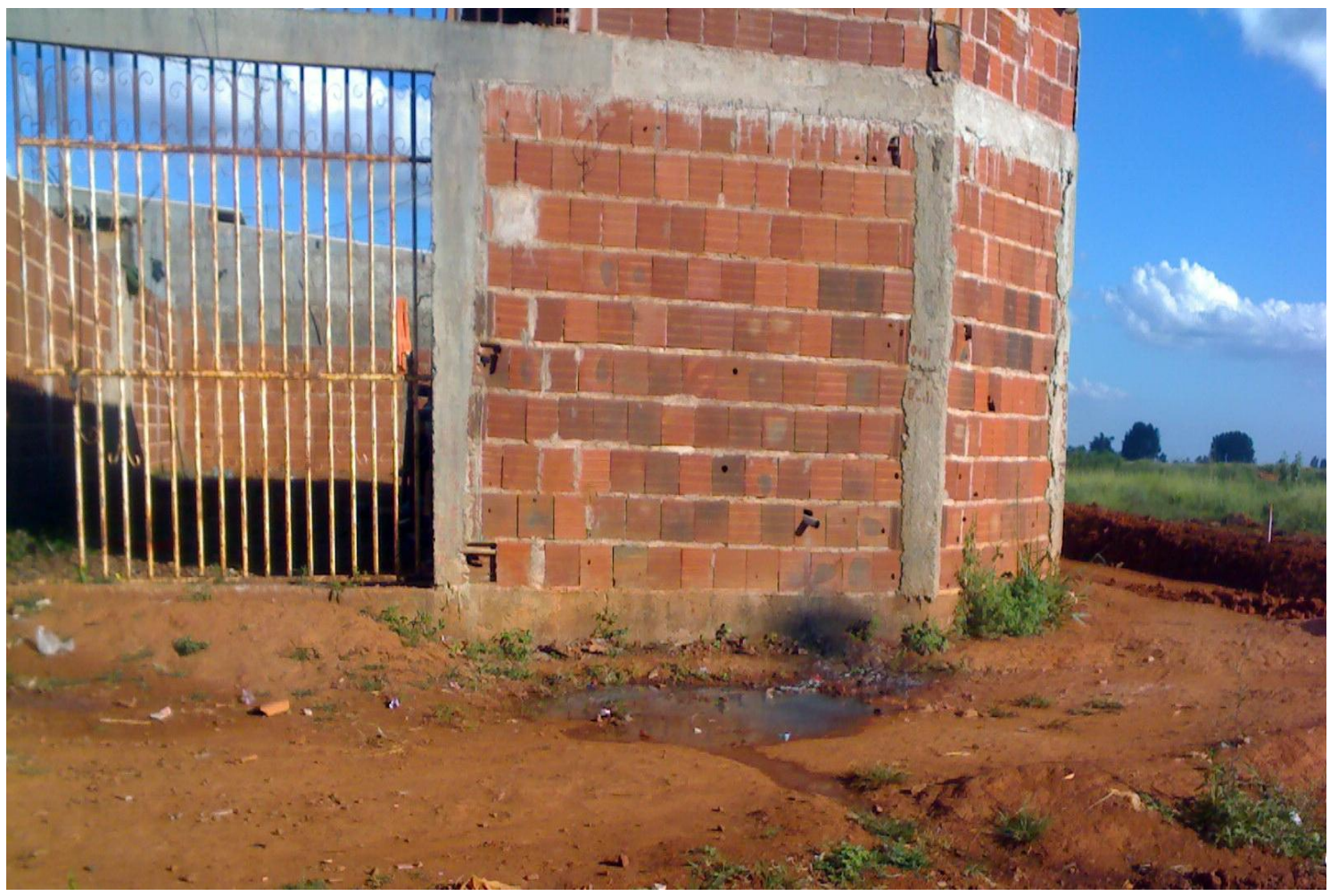

Foto: Bruno da Costa Monteiro, 04 de Junho de 2009.

Todas as casas utilizam fossas como forma de eliminar o esgoto, porém, como foi mostrado nos estudos hidrológicos feitos antes da construção das residências, deveriam ser tomado alguns cuidados especiais caso fosse utilizado fossas. Com base no relatório sobre estudos hidrológicos sabe-se que o solo é raso, com profundidades que variam de $4,50 \mathrm{~m}$ a $1,00 \mathrm{~m}$.

As pessoas foram construindo fossas, desde o primeiro processo de ocupação do território, estas fossas deveriam ser esvaziadas pelo governo, porém, não foi isso que aconteceu, pois, o governo não dá ajuda nenhuma para limpeza de fossas e este serviço é feito por empresas particulares. O problema esta no fato de que nem todos os moradores têm condições de pagar e acabam deixando o esgoto transbordar. É comum andar nas ruas e encontrar residências que tiveram suas fossas transbordando, a Fotografia 3 mostra um exemplo de fossa que trasbordou devido ao excesso de uso, é possível notar este excesso acaba surgindo para as ruas e com o tempo infiltrará no solo, sujando o lençol freático. 
FOTOGRAFIA 3 - Exemplo de fossa transbordando, QNR 04

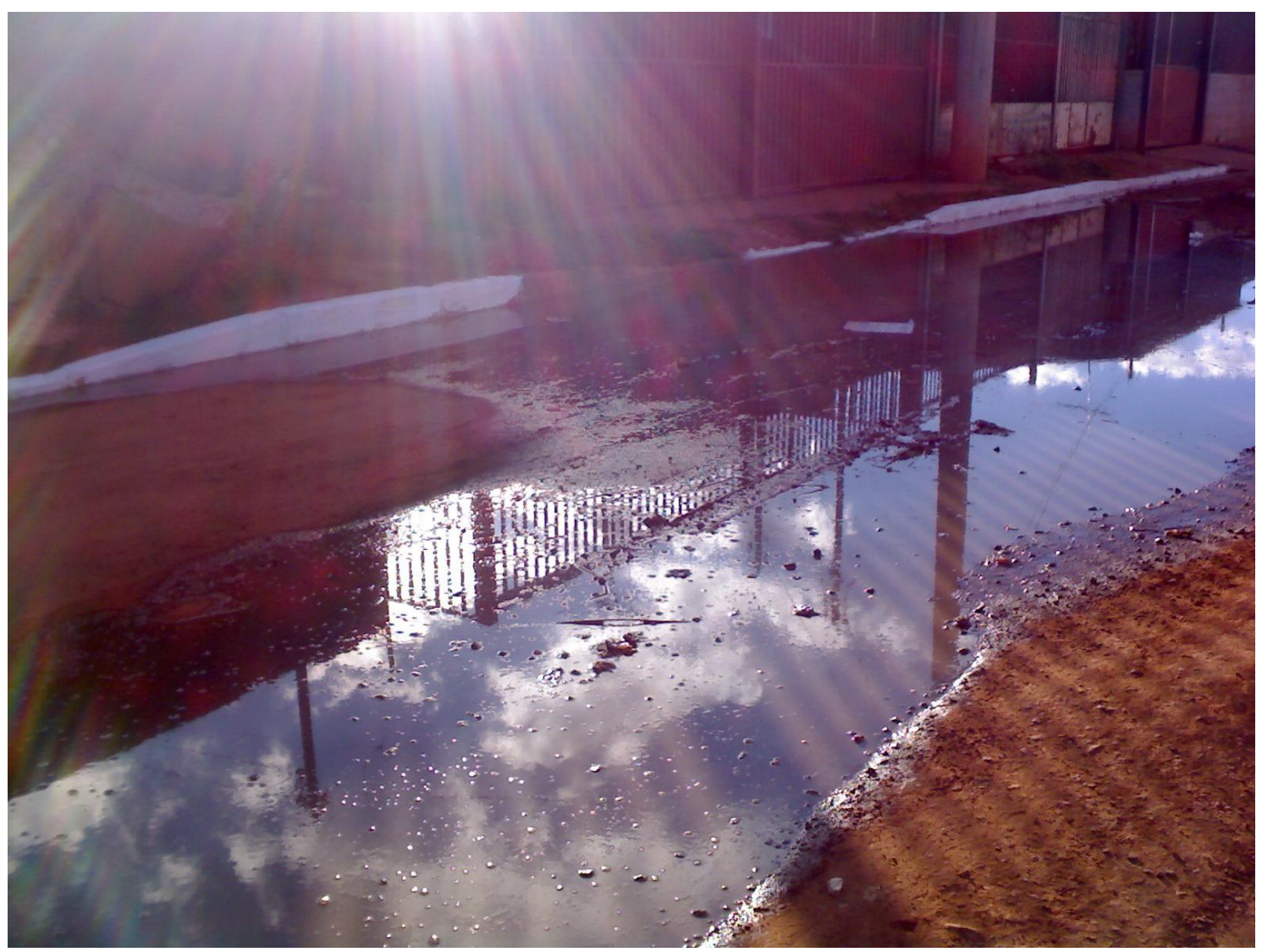

Foto: Bruno da Costa Monteiro, 04 de Junho de 2009.

A Fotografia 3 mostra um caso comum em toda a extensão da Nova QNR, o que é mais alarmante nesta foto é o fato desta fossa estar transbordando em frente ao Galpão Comunitário, que encontra-se na QNR 04, como mostra a Fotografia 4. Este galpão oferece comida duas vezes por semana e é bem provável que os moradores possam estar comendo uma comida contaminada por moscas que ficam nas fossas transbordadas, bem como pelo vento que pode adentrar no galpão comunitário. 
FOTOGRAFIA 4 - Galpão Comunitário, QNR 04, nas proximidades de uma fossa

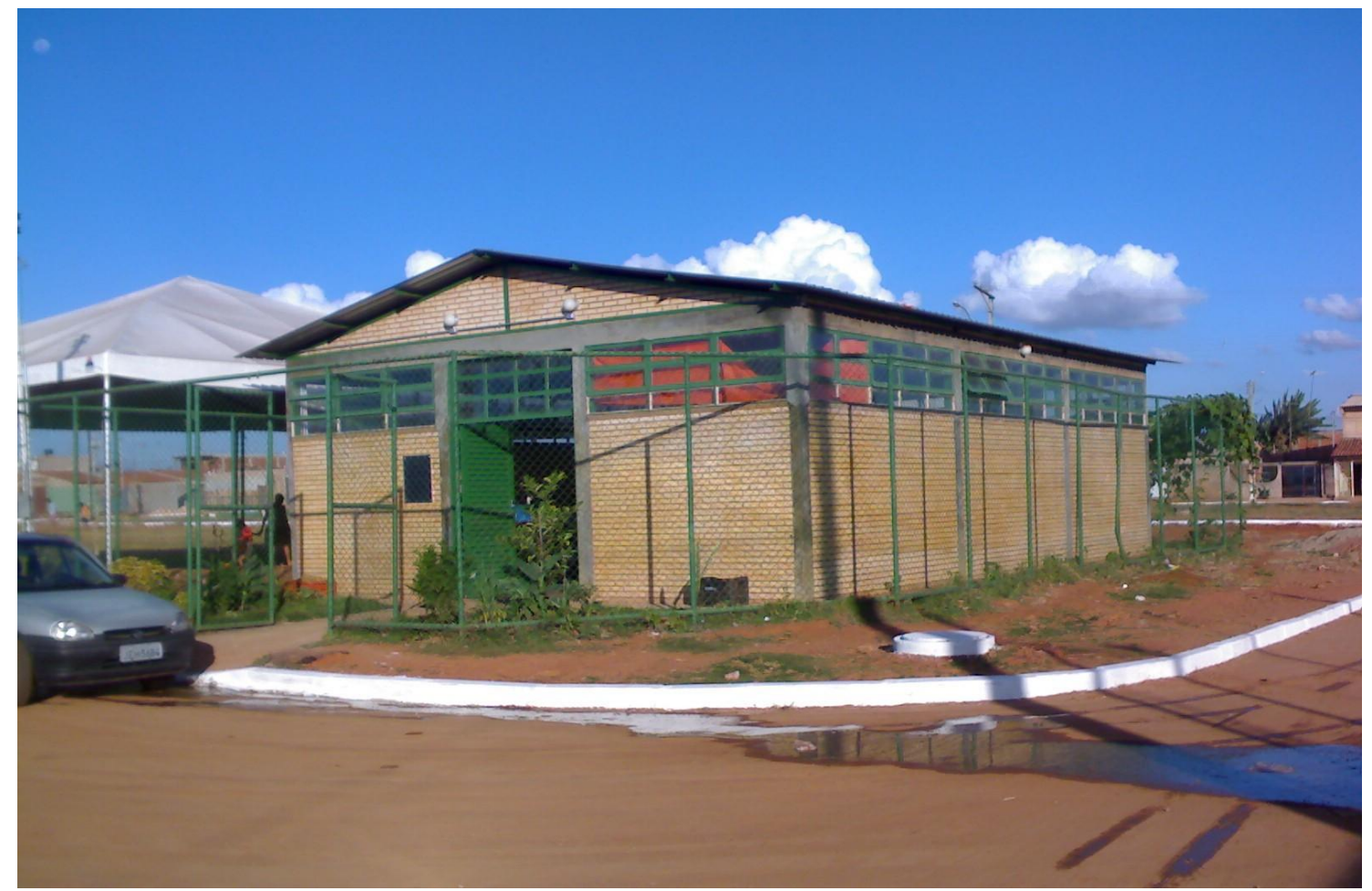

Foto: Bruno da Costa Monteiro, 04 de Junho de 2009.

Esta contaminação do solo e consequentemente do lençol freático está prejudicando os moradores da região. Alguns deles estão bebendo água suja, como é o caso da QNR 3, onde foi encontrado alguns canos com vazamentos que estão em contato direto com o lençol freático.

Outro problema, constatado nas saídas de campo, é a coleta de lixo, que era feita sem freqüência e somente em algumas quadras da Nova QNR, dentre elas a 2 e a 5 pela parte externa. Os moradores da região disseram que a desculpa utilizada pelos catadores de lixo é o fato de não terem condições de adentrarem nas quadras, devido aos buracos existentes nas ruas e o medo de atolarem com o caminhão. Devido a este fato o lixo acabava sendo empilhado em uma determinada região atraindo ratos, baratas e consequentemente causando doença aos moradores. A Fotografia 5, retirada na primeira saída de campo mostra um cachorro rasgando o saco de lixo. O caminhão da coleta de lixo havia passado no dia anterior ao dia da foto, porém, é notável que já havia começado a aglomerar lixo nos postes. 
FOTOGRAFIA 5 - Via entre a as residências da QNR 02 e as áreas especiais.

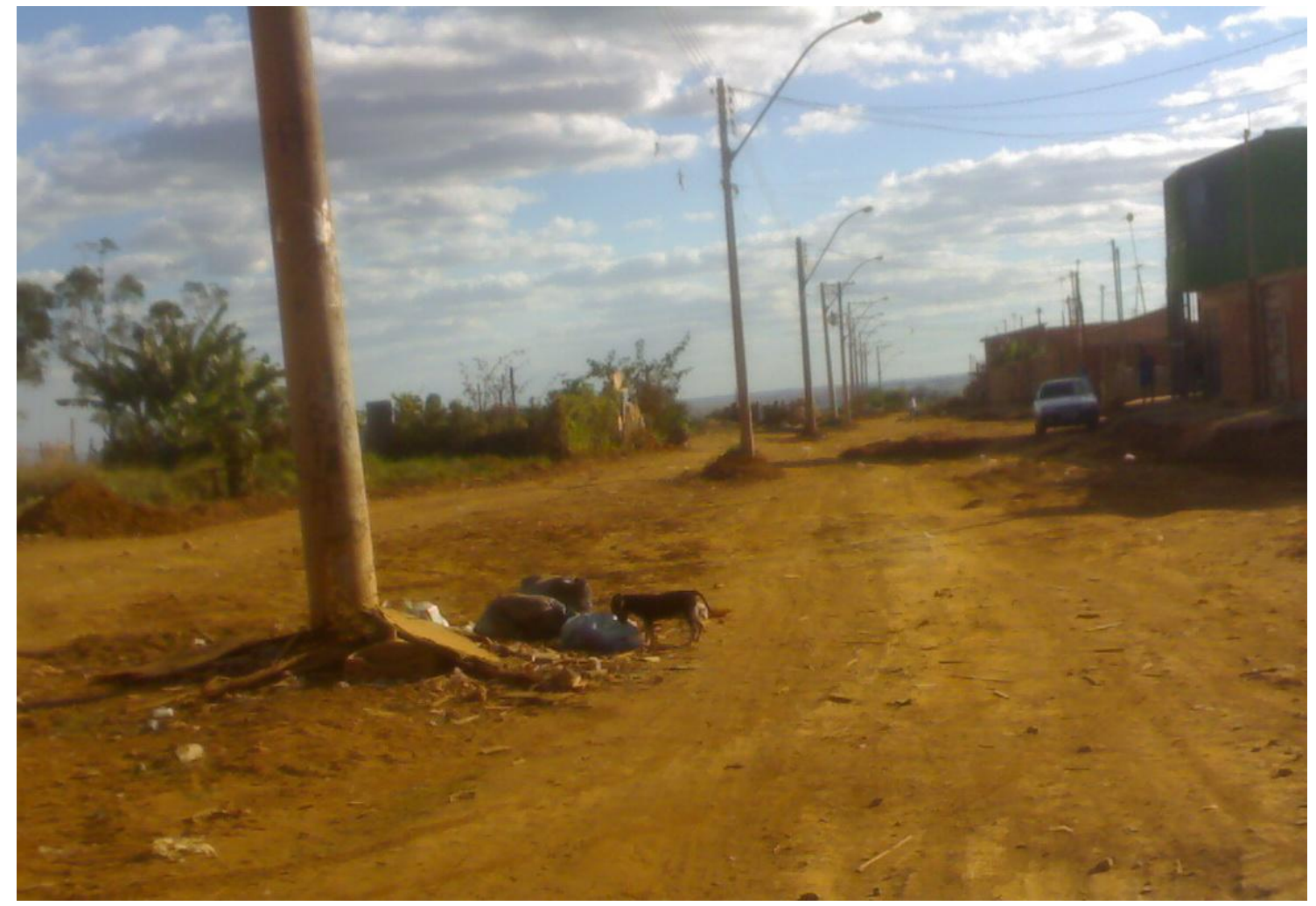

Foto: Bruno da Costa Monteiro, 05 de Junho de 2008.

O lixo acumulado acaba gerando chorume, que é um líquido poluente e de cheiro forte, que ao entrar em contato direto com o solo acabam poluindo-o. Quando existe acúmulo de chorumes e juntam-se com as chuvas estes poluentes vão até os lençóis freáticos.

Com a última saída de campo, foi constatado que esta região já estava asfaltada, porém, a coleta de lixo era feita somente três vezes por semana. As áreas que não estavam asfaltadas, como as áreas especiais, acabavam se tornando depósitos de lixo e restos de construção, como é mostrado na Fotografia 6. 
FOTOGRAFIA 6 - Lixos acumulados na Área Especial da QNR 02



Foto: Bruno da Costa Monteiro, 04 de Junho de 2009.

A fotografia acima mostra restos de construções junto com lixo. Os problemas mostrado nesta fotografia são devidos aos entulhos acumulado junto com o lixo por grande tempo trazendo ratos e baratas e outros insetos decompositores, outro problema ocorre quando chove, pois com o acúmulo do lixo haverá poluição do solo e consequentemente do lençol freático por infiltração. Em época de seca o vento acaba trazendo poeira misturada com poluentes do lixo, causando doenças respiratórias principalmente nas crianças.

Outro problema de vulnerabilidade socioambiental, constatado nas saídas de campo é sobre o asfaltamento. Na primeira saída de campo foi constatado que nenhuma rua da Nova QNR estava asfaltada. Os moradores sofriam com a poeira que se misturava com águas servidas e em alguns casos com fossas transbordadas. Esta poeira causa sérios problemas para as crianças que, em grande parte brincavam descalças em meio ao solo exposto. 
Já na segunda saída de campo, quase todas ruas já estavam asfaltadas, com exceção da via que passa na frente da Escola Classe 65 e também do Parque das Coruja, como mostra a Fotografia 7. A poeira desta construção acaba prejudicando as crianças da escola, pois o muro da mesma é baixo. Não é possível ver na imagem, mas o esgoto será implementado a partir desta via, subindo e ligando às residências. O motivo da demora da construção do asfalto nesta localidade é devido ao fato desta área ser mais próxima do lençol freático e necessitar de cuidados especiais.

FOTOGRAFIA 7 - Única via da Nova QNR ainda não asfaltada

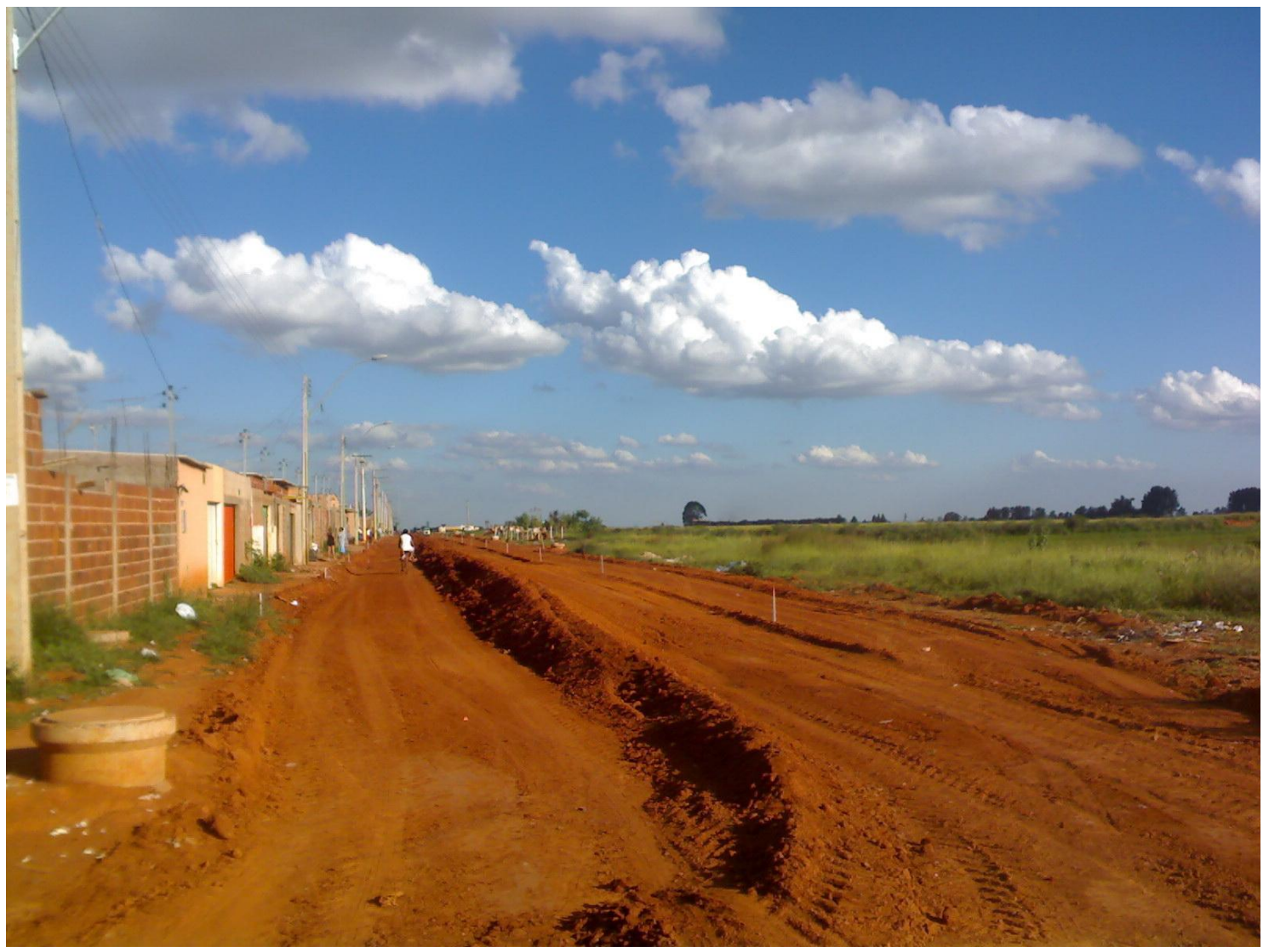

Foto: Bruno da Costa Monteiro, 04 de Junho de 2009.

Nas saídas de campo pode-se notar que grande parte dos lotes já foram vendidos para outros donos, fazendo com que o nível de renda entre os moradores cresça um pouco mais. Este fato veio aparecer recentemente na mídia, pois as casas da QNR 5 são proibidas de serem vendidas e apesar de haver esta venda ilegal o que ainda predomina é a classe mais pobre. É comum ainda encontrarmos casas com madeirites e como portão apenas um arame farpado, como mostra na Fotografia 8. 
FOTOGRAFIA 8 - Residência da QNR 05 de frente com a BR 070

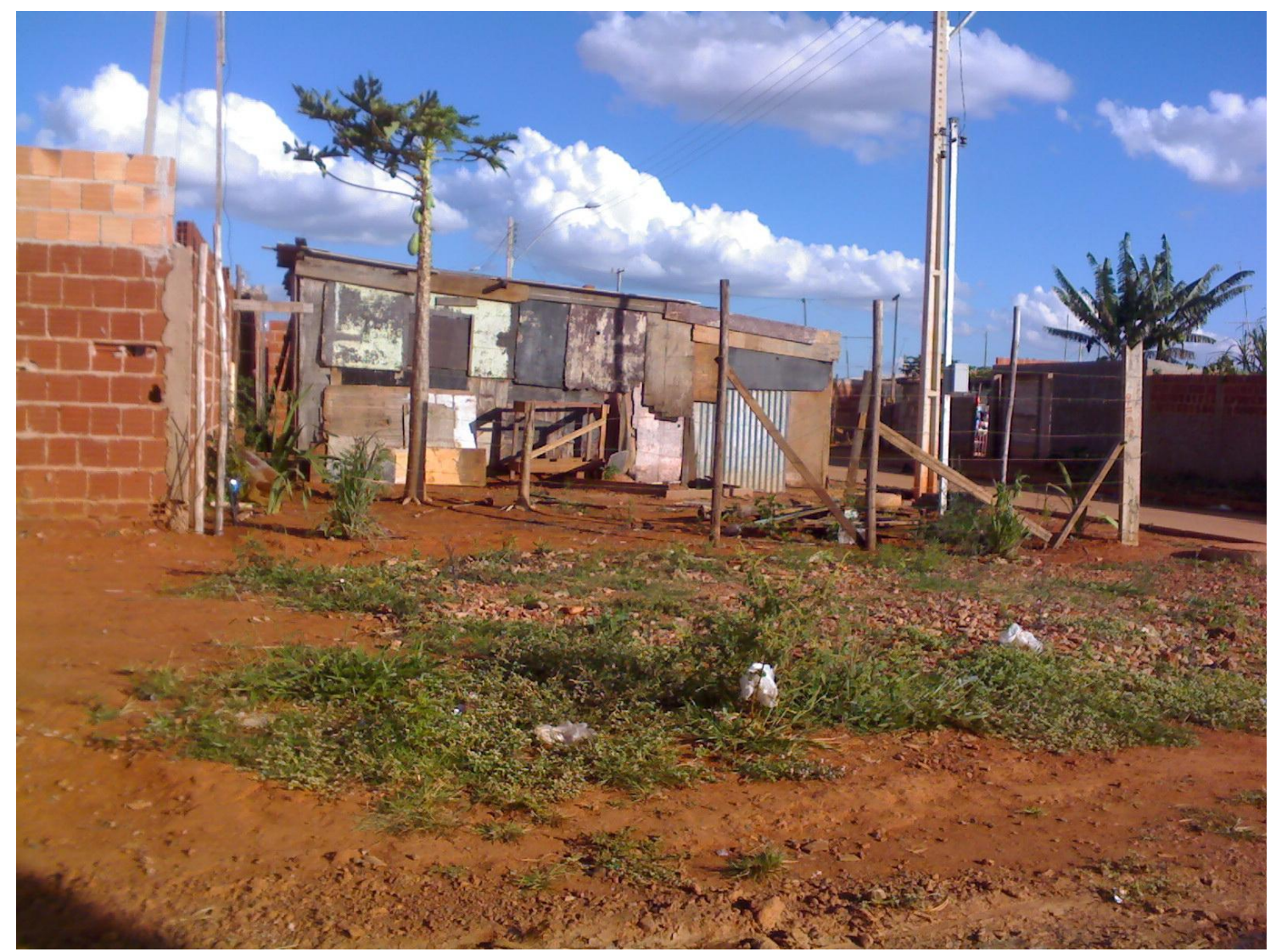

Foto: Bruno da Costa Monteiro, 04 de Junho de 2009.

A fotografia acima mostra um problema comum devido ao fato do governo ter removido os moradores das antigas favelas sem ajuda nenhuma. Os moradores das antigas invasões são pessoas com pouca instrução, como baixa renda e sem condições de melhorar as casas.

O posto de saúde mais próximo encontra-se na QNQ 07, acima da QNR 1 e a distância entre um morador da QNR 5 até este posto é de quase 3 quilômetros, este posto costuma ajudar a escola com pediatras, que vão até a escola atender alguns alunos mais necessitados.

Apesar de existir um terminal, na área especial da QNR 2 os moradores têm que se deslocar aproximadamente 1,0 quilômetro para conseguirem utilizar transporte público para algumas áreas dentro do Distrito Federal. Existem poucas linhas que passam na via principal, porém estes ônibus não são freqüentes e muitas vezes um morador pode ficar mais do que 30 minutos na parada para ver um ônibus passar por ali. 
Existe ainda um problema relacionado a energia, que chegou às residências da Nova QNR no dia 28 de setembro de 2004, por meio de cabos elétricos passando por cima dos postes. A Escola Classe 65, fundada em 2006, recebeu energia de uma forma diferente, por fios que passam por debaixo da mesma. A escola encontra-se num nível mais baixo das quadras residenciais e os problemas começaram a aparecer, pois, a água do lençol freático acabou subindo e inundando os fios. Os alunos e os professores estão correndo sérios riscos de tomarem choques, pois com a época de chuva o solo fica quase todo inundado e em contato direto com os fios de alta tensão.

Esta escola enfrenta sérios problemas devido à falta de infra-estrutura nas residências da QNR. Os alunos, em grande parte têm piolhos, vermes e doenças relacionadas a falta de saneamento como disenteria, hepatite, doenças de pele entre outras. A diretora da escola conta que em 2007 teve hepatite. Devido esta escola ser a única no local, o que é uma falta de infra-estrutura, ela não consegue atender todas as crianças das QNR e também do Sol Nascente, região que encontra-se ao lado, devido ao grande número de crianças existente nas nestas quadras. Com isso as crianças têm que buscar outras escolas com distância que podem chegar a mais de três quilômetros.

A Escola foi construída com cinco fossas e quatro sumidouros, contudo os sumidouros começaram a dar problemas devido às fossas que estão enchendo de água, o problema só não é maior porque a água que transborda acaba voltando para o ralo do banheiro.

$\mathrm{Na}$ maioria das vezes a escola faz o papel de posto de saúde, quando conseguem parcerias com instituições para ajudar as pessoas carentes, porém, a ajuda fornecida nem sempre é suficiente, pois os moradores, em grande parte, estão com grandes problemas devido aos problemas relacionados acima. A diretora conseguiu parceria com a ação global e os mesmos se dispuseram em ajudar trazendo um laboratório para fazer exames de fezes e urina dos alunos, e o resultado foi algo alarmante, pois existem criança com dez tipos de vermes, cristais nas urinas por causa da alimentação, problema de infecção urinária entre outros.

Como foi mostrado neste capítulo, existe problemas muito grande nesta região, onde os moradores sem necessidade acabam sofrendo por problemas de saúde. Grande parte dos problemas é devido à má utilização do solo, mas este não é um problema fácil de resolver, tendo em vista que os moradores nem sempre têm condições de se manterem em melhores condições de vida ou de evitarem problemas como é o caso da contaminação do solo que é muito freqüiente. 
Devido à enorme falta de infra-estrutura e de equipamentos urbanos na localidade a única escola existente na localidade acaba que fazendo a função de outros equipamentos comunitários como no caso a de servir de posto de saúde para as crianças estudantes, o que acaba sobrecarregando as tarefas exercidas pelo o estabelecimento. Os problemas relacionados à vulnerabilidade socioambiental desta região são notáveis e os moradores não têm condições de melhorias devido ao nível econômico da região bem como do esquecimento por parte do governo no cumprimento das ações. 


\section{CONSIDERAÇÕES FINAIS}

Entendendo a história de Brasília e da Ceilândia é possível perceber que quando o planejamento é posto em prática os moradores acabam sendo beneficiados. Foi notável que a Ceilândia foi bem cuidada somente nas suas primeiras construções e os moradores que vieram depois foram sofrendo com a falta de infra-estrutura até chegarmos às quadras da Nova QNR, que não receberam nenhuma em sua fase de ocupação. A falta de políticas públicas acabou gerando problemas para a região em estudo e também para as regiões próximas, como é o caso dos postos de saúde próximos a Nova QNR, que acabam que lotando devido às doenças e outros problemas, gerados devido à péssima infra-estrutura.

Existem projetos que tentam minimizar os riscos, porém os moradores destas quadras precisam de ações governamentais imediatas, com pelo menos a implantação do que já foi proposto na Tabela 2, com base nos Parâmetros Urbanísticos Básicos, proposto em março de 2002 pela TOPOCART. Apesar de alguns projetos já estarem em sua fase de execução, é necessário cobrar ações do governo para aquelas que ainda faltam ser cumpridas, como exemplos: a coleta de lixo diária; coleta da rede de esgoto de forma que não polua o lençol freático; um posto de saúde para atender esta comunidade e as comunidades próximas; uma escola de ensino básico e médio para os estudantes desta região e das regiões próximas; de um posto policial para melhorar a segurança. Estas são as principais, e que necessitam de urgência.

Como um todo, este trabalho mostra que os moradores da região estudada estão morando em áreas de vulnerabilidade devido à falta de atenção do governo com os moradores, mesmo havendo planejamentos. Procurou-se utilizar indicadores ambientais como degradação ao meio ambiente bem como indicadores sociais como exposição dos moradores ao risco. A partir destes indicadores foi possível notar que nas áreas de maior degradação e de risco moravam as pessoas com menor poder aquisitivo e isto mostra que eles encontram-se vulneráveis e incapazes de reagir aos problemas. Agora que o problema já esta em todas as residências da Nova QNR, existe uma grande dificuldade de modificar o ambiente sem gerar maiores problemas.

O Capítulo 2 buscou enfatizar a história do Distrito Federal, fazendo uma breve relação com a ocupação territorial em locais próximos de Brasília e a retirada dos moradores irregulares para outras localidades, no caso Ceilândia. 
Já o Capítulo 3 visa responder a primeira pergunta do trabalho, "Como se relaciona a forma de ocupação que veio ocorrendo no território de Ceilândia com a ocupação das quadras periféricas?" e é percebido neste capítulo que Ceilândia ao longo do tempo foi melhorando as quadras já consolidas e dando menos atenção as quadras que mais precisam de apoio para sua consolidação. Ainda com base no Capítulo 3, também é possível responder parte da segunda pergunta do trabalho, que busca entender qual é o papel do governo na constituição de áreas de risco e vulnerabilidade socioambiental na Nova QNR, o papel do governo neste caso é o de omissão, pois como foi mostrado neste capítulo, as quadras de maior necessidade é onde encontramos menos apoio do governo.

O Capítulo 4 mostra de forma concreta que o papel do governo que seria o de dar apoio e evitar a existência de áreas de risco e vulnerabilidade socioambiental é quase nulo. Mostra os problemas que ocorrem quando os moradores não recebem a assistência necessária. Ainda com base no capítulo 4 foi possível entender os dois objetivos específicos, mostrando que existe uma relação entre a ocupação na Ceilândia com as ultimas quadras e verificar que não ouve ação do governo na prática somente no planejamento.

Caso exista um novo estudo sobre esta área, será importante fazer uma comparação histórica, levando em consideração os problemas que os moradores enfrentaram em 2008 e 2009 para entender o que realmente mudou no âmbito socioambiental. 


\section{REFERÊNCIAS}

100PORCENTOCEILANDIA. Remoção. 07 jun. 2008. Disponível em: <http://100porcentoceilandia.blogspot.com/search/label/QNR>. Acesso em: 22 nov. 2008.

ALMEIDA, Laura Maria P. Vulnerabilidade Social. Disponível em: <http://www.cavanis.org.br/dow/geral/historico_social.pdf>. Acesso em: 18 jun 2009.

Alves, H. P. da F. Vulnerabilidade socioambiental na metrópole paulistana: uma análise sociodemográfica das situações de sobreposição espacial de problemas e riscos sociais e ambientais. Rev. bras. estud. popul. 2006, vol. 23, no. 1, pp. 43-59.

Anais XIII Simpósio Brasileiro de Sensoriamento Remoto, Florianópolis, Brasil, 21-26 abril 2007, INPE, p. 2493-2500

ARGILES, Nara R. Leal. Análise das relações e influências do modelo de planejamento estratégico urbano no plano diretor de desenvolvimento urbano ambiental de porto alegre - PDDUA. 151 f. Dissertação (mestrado) - Universidade Federal do Rio Grande do Sul. 2003.

BRANDÃO, A; LINS, L. "Bases para uma política urbana e de habitação no Brasil”. Mimeografado. Brasília. 1998.

Brasil/Serviço Federal de Habitação E Urbanismo. Planejamento metropolitano. Rio de janeiro: Serfhau, 1972. 2 v.

BUARQUE, Sérgio C. Metodologia de planejamento do desenvolvimento local e municipal sustentável. Brasília 2009. Disponível em: <http://www.iica.org.br/Docs/Publicacoes/PublicacoesIICA/SergioBuarque.pdf>.

Acesso em: 12 jun. 2009

Ceilândia: Resgate Histórico, Brasília: Ed. Brasília, 2005. 2 ed. 48p.

DISTRITO FEDERAL. Modelo de gestão estratégica do território do Distrito Federal. Brasília: Metroquattro Arquitetura Tecnologia, 2004. 172 p.

FONSECA, Cesar Magalhães. Análise dos instrumentos EIA e Rivi na gestão do Espaço urbano: sub-bacia do Ribeirao Mestre D’Armas. Brasília, 165 p. Dissertação (Mestrado). UnB, 2007.

FURTADO, Manoel Alves. Ceilândia Diagnóstico. Brasília: 2003. 79 p.

GDF. Ações de Governo. Disponível em: <http://www.distritofederal.df.gov.br/sites/ 000/53/00002952.pdf>. Acesso em: 12 nov. 2008.

GDF. Aspectos Históricos. 2006. Disponível em: <http://www.ceilandia.df.gov.br/005/00502001.asp? ttCD_CHAVE=4291>. Acesso em: 12 nov. 2008. 
GDF. De invasão a cidade organizada. 21 jan. 2008 Disponível em: <http://www.df.gov.br/003/00301009.asp?ttCD_CHAVE=57917>. Acesso em: 13 nov. 2008 .

GDF. Famílias são transferidas de invasão na Ceilândia para área em Samambaia. 09 jun. 2008. Disponível em: <http://www.codhab.df.gov.br/paginas/imprensa/exibicao_de_noticia_011.htm>. Acesso em: 22 nov. 2008.

GDF. GDF entrega mil escrituras de dez cidades. 13 out. 2008. Disponível em: <http://www.codhab.df.gov.br/paginas/imprensa/exibicao_de_noticia_032.htm>.

Acesso em: 22 nov. 2008.

GDF. Norma técnica para equipamentos comunitários e urbanos. Disponível em: <www.semarh.df.gov.br/sites/300/379/00000720.pdf>. Acesso em: 12 jun 2008

GDF. Pró-Moradia beneficiará o PNorte. 28 fev. 2008. Disponível em: <http://www.ceilandia.df.gov.br/003/00301009.asp?ttCD_CHAVE=59171>. Acesso em: 05 maio 2009.

GDF. Roriz acompanha remoção de famílias do Pelezão e diz que vai ajudar de acordo com a lei. 09 set. 2004. Disponível em: <http://www.gdf.df.gov.br/003/00301009.asp?ttCD_CHAVE=5349>. Acesso em: 05 jun. 2008

GDF. Roriz leva iluminação pública para Vila Feliz. 28 set. 2004. Disponível em: <http://www.distritofederal.df.gov.br/003/00301009.asp?ttCD_CHAVE=5914>. Acesso em: 05 jun. 2008.

GDF. Tudo sobre o Distrito Federal - A visão de Juscelino Kubitscheck. Disponível em: <http://www.setur.df.gov.br/003/00301020.asp?ttCD_CHAVE=10235>. Acesso em: 12 jun 2009.

GDF. Vice-governadora acompanha remoção dos moradores do Pelezão. 08 set. 2004. Disponível em: <http://www.distritofederal.df.gov.br/003/00301009.asp?ttCD_ CHAVE=5281>. Acesso em: 05 jun. 2008.

Secretaria de Estado de Desenvolvimento Urbano e Habitação do DF - SEDUH. Modelo de gestão estratégica do território do Distrito Federal. Brasília, setembro de 2004. p. 27.

GUIA DE BRASÍLIA. Regiões administrativas do DF. Disponível em: <http://www.guiadebrasilia.com.br/cidade/dadostxt/ra_texto.html>. Acesso em: 13 nov. 2008.

MINISTÉRIO DAS CIDADES. Começam mais obras do PAC de urbanização e saneamento. 06 jun. 2008. Disponível em: <http://www.cidades.gov.br/ noticias/comecam-mais-obras-do-pac-de-urbanizacao-e-saneamento> Acesso em: 22 nov. 2008 
MORAES, Luciana Batista. Comércio informal e organização espacial no centro urbano de Ceilândia, Distrito Federal. 138 f. Dissertação (mestrado) - Universidade de Brasília, Departamento de Geografia. 2004.

OLIVEIRA, Ana Izabel Cardoso de. Gestão do território, violência, práticas policiais e representação social do lugar: uma abordagem da Ceilândia, Distrito Federal. 2006. 167 p. Dissertação (mestrado) - Universidade de Brasília, Instituto de Ciências Humanas, Departamento de Geografia, Programa de Pós-Graduação em Geografia, 2006.

OLIVEIRA, Mirna Augusto. Distribuição espacial da população no distrito federal Características dos movimentos migratórios inter-regionais. Secretaria de Estado de Planejamento. Brasília/DF, 2006. Disponível em: <http://www.seplan.df.gov.br/sites/100/146/00000023.pdf>. Acesso em: 17 nov. 2008.

PELUSO, Marília Luiza; OLIVEIRA, Washington Candido de. Distrito Federal: paisagem, população \& poder. São Paulo: Harbra, 121 p.

PASCOAL, Guto. Ocupações revelam déficit habitacional. Com Ciência - Cidades, mar. 2002. Disponível em: <http://www.comciencia.br/reportagens/cidades/cid05.htm>. Acesso em: 11 jul. 2008.

TOPOCART. Planilha de Parâmetros Urbanísticos, 2002. 05 p.

SABOYA, Renato. Planejamento estratégico de cidades - parte 1, 2008. Disponível em: <http://urbanidades.arq.br/2008/05/planejamento-estrategico-de-cidades-parte-1>. Acesso em: 11 jun 2009.

SABOYA, Renato. O surgimento do planejamento urbano, 2008. Disponível em: <http://urbanidades.arq.br/2008/03/o-surgimento-do-planejamento-urbano>. Acesso em: 21 jun 2009.

SANTOS, Milton. Por uma geografia nova. São Paulo: Hucitec/EDUSP, 1978.

SECRETARIA DO ESTADO E DE OBRAS DO DISTRITO FEDERAL. Obras que beneficiam a comunidade da Região Administrativa IX Ceilândia. Disponível em: <http://www.so.df.gov.br/005/00502001.asp?ttCD_CHAVE=3920>. Acesso em: 12 nov. 2008.

SILVA, Ernesto (1983). História de Brasília: um sonho, uma esperança, uma realidade. Brasília: Coordenada.

SILVA, Maria \& SOUZA, Maria. Itabira - Vulnerabilidade Ambiental: impactos e riscos socioambientais advindos da mineração em área urbana. Disponível em: <http://www.abep.nepo.unicamp.br/docs/anais/pdf/2002/GT_MA_ST37_Silva_texto.pd f>. Acesso em: 30 nov. 2008.

SOARES, Ana Lúcia Barreto; Peixoto, Iraci M. D. Moreira. Coletânea de informações socioeconômicas: XX - Águas Claras. Companhia de Planejamento do Distrito 
Federal, Brasília/DF

nov. $\quad 2006$.

Disponível

em:

<http://www.codeplan.df.gov.br/sites/200/216/000000.pdf>. Acesso em: 19 out. 2008. 